\title{
Habilitacja jako warunek awansu naukowego w Polsce w latach 1990-2018
}

\section{Wprowadzenie}

O habilitacji w polskich rozwiązaniach prawnych można mówić, począwszy od pierwszych lat odzyskania niepodległości. Instytucja habilitacji wprawdzie przetrwała do czasów współczesnych, jednak warunki prowadzące do jej przeprowadzania na przestrzeni lat zmieniały się. Odpowiednio do nich zmieniały się także drogi awansu naukowego i zawodowego. W latach minionych pozytywne zakończenie postępowania habilitacyjnego nie zawsze wiązane było z nabyciem stopnia naukowego. $Z$ kolei uzyskanie wyższego stopnia naukowego nie zawsze utożsamiano z habilitacją.

W okresie II Rzeczypospolitej ${ }^{1}$ i w pierwszych latach Polski Ludowej ${ }^{2}$ pomyślnie zakończone postępowanie habilitacyjne w państwowych szkołach akademickich wiązano z udzieleniem kandydatowi prawa wykładania (veniam legendi) ${ }^{3}$. Nabycia tego uprawnienia w żadnym razie

${ }^{1}$ Ustawa z dnia 13 VII 1920 r. o szkołach akademickich (Dz.U. RP Nr 72, poz. 494 ze zm.) oraz Ustawa z dnia 15 III 1933 r. o szkołach akademickich (tekst jedn. Dz.U. RP $1938 \mathrm{Nr}$ 1, poz. 6 ze zm.).

${ }^{2}$ Dekret z dnia 28 X 1947 r. o organizacji nauki i szkolnictwa wyższego (Dz.U. Nr 66, poz. 415). Zob. też Rozporządzenie Ministra Oświaty z dnia 21 VI 1945 r. w sprawie postępowania habilitacyjnego w państwowych szkołach akademickich (Dz.U. Nr 24, poz. 139) oraz Zarządzenie Ministra Oświaty z dnia 3 VII 1948 r. w sprawie tymczasowego nadania prawa habilitowania państwowym szkołom akademickim (Dz.Urz. Ministerstwa Oświaty Nr 9, poz. 146).

${ }^{3} \mathrm{~W}$ państwowych szkołach akademickich - z tytułem docenta, jeżeli te przewidywały jego zatrudnienie, bądź docenta prywatnego. Tego pierwszego mianował Minister Wyznań Religijnych i Oświecenia Publicznego na wniosek senatu bądź rady profesorów 
nie łączono z nadaniem stopnia naukowego. Nadal wyższym stopniem pozostawał stopień naukowy doktora. Lata późniejszych rozwiązań prawnych (1952-1958) wprawdzie także przewidywały nadawanie wyższego stopnia naukowego, tyle że odwołując się do wzorców radzieckich, przyjęto, iż odtąd jest nim stopień naukowy doktora nauk ${ }^{4}$. Od tego rozwiązania odstąpiono dość wcześnie. Ustawą z 1958 r. o szkolnictwie wyższym ${ }^{5}$ przywrócono habilitację - prowadzącą do nabycia wyższego stopnia naukowego docenta. I tego stanu rzeczy wiele nie zmieniło wyłączenie ustawą z roku $1965^{6}$ spraw nadawania stopni i tytułów naukowych spod regulacji prawa szkolnictwa wyższego i poddanie przewodów habilitacyjnych w latach następnych odrębnym regulacjom ustawowym - z 19907 i 2003 r. ${ }^{8}$ Rozwiązania przyjęte w tych latach nie były również takie same. W głównej mierze objęto nimi: dziedziny nauki i dyscypliny naukowe, w których mogły być nadawane stopnie naukowe; warunki i tryb przeprowadzania czynności w przewodach (od $2011 \mathrm{r}$. w postępowaniach) habilitacyjnych, jak i podmioty uprawnione do ich prowadzenia, a także procedurę zatwierdzania uchwał właściwych rad w sprawie nadania stopnia naukowego doktora habilitowanego.

Ustawa z 1990 r. o tytule naukowym i stopniach naukowych, uchylając ustawę wcześniejszą (z 1965 r.), mimo że rok ten wraz z transformacją ustrojową przyniósł nowe spojrzenie na sprawy ważne dla państwa i społeczeństwa, nie zrewolucjonizowała prawa prowadzącego do nabycia wyższego stopnia naukowego. Nie oznacza to, że nie wprowadzono nią i wydanymi na jej podstawie aktami wykonawczymi nowych rozwiązań i że nie podlegały one w okresie trzynastu lat jej

pod rządami ustawy z 1920 r. o szkołach akademickich; rady wydziałowej i senatu pod rządami ustawy z 1933 r. o szkołach akademickich. Docenci prywatni nie byli mianowani przez władze państwowe, mieli jedynie prawo wykładania w szkole akademickiej (i wynagrodzenia ze środków finansowych danego wydziału) oraz korzystania z jej sal wykładowych. Nie przekreślało to ich dalszej kariery naukowej w szkołach akademickich. W pierwszych latach Polski Ludowej pomyślnie zakończona habilitacja prowadziła do uzyskania tytułu naukowego docenta; docentów etatowych mianował Minister Oświaty.

${ }^{4}$ Ustawa z dnia 15 XII 1951 r. o szkolnictwie wyższym i pracownikach nauki (Dz.U. $1952 \mathrm{Nr} 6$, poz. 38 ze zm.). Niższym stopniem naukowym był stopień kandydata nauk.

${ }^{5}$ Ustawa z dnia 5 XI 1958 r. o szkołach wyższych (Dz.U. Nr 68, poz. 336 ze zm.).

${ }^{6}$ Ustawa z dnia 31 III 1965 r. o stopniach naukowych i tytułach naukowych (Dz.U. Nr 14, poz. 101 ze zm.).

${ }^{7}$ Ustawa z dnia 12 IX 1990 r. o tytule naukowym i stopniach naukowych (Dz.U. Nr 65, poz. 386 ze zm.). Ustawa weszła w życie z dniem 27 IX $1990 \mathrm{r}$.

${ }^{8}$ Ustawa z dnia 14 III 2003 r. o stopniach naukowych i tytule naukowym oraz o stopniach i tytule w zakresie sztuki (Dz.U. Nr 65, poz. 595 ze zm.). Ustawa weszła w życie z dniem 1 V 2003 r. 
obowiązywania zmianom. Pozytywną stroną bez wątpienia było ich wdrażanie drogą ewolucyjną. To, co takiego charakteru nie miało, a miało - na wzór rozwiązań okresu międzywojennego - wartość znacząca, to zdecydowanie nowe podejście do polityki naukowej i nauki ${ }^{9}, \mathrm{w}$ konsekwencji lepiej służące prowadzeniu badań naukowych i swobodnej ocenie prawa i faktów prezentowanych w pracach naukowych, w tym w pracach prowadzących do uzyskania wyższego stopnia naukowego. I od tego założenia nie odstąpiono w latach późniejszych przemian prawa szkolnictwa wyższego.

Założenia tego nie deprecjonowała także Ustawa z dnia 14 marca 2003 r. o stopniach naukowych i tytule naukowym. Nie oznacza to, że ustawy tej (oraz wydanych na jej podstawie aktów wykonawczych) w okresie blisko piętnastu lat jej obowiązywania nie poddawano zmianom. W odróżnieniu od ustawy pierwszej (z 1990 r.) drogi prowadzące do ich wdrażania były jednak różne. Zdecydowanie ewolucyjny sposób cechował zmiany wprowadzone w latach 2003-2011. W przeciwnym kierunku zmierzały natomiast propozycje prawodawcy w okresie poprzedzającym wdrożenie ustawowej noweli w 2011 r. Zakładały one konieczność odstąpienia od habilitacji i stopnia naukowego doktora habilitowanego. Środowisko naukowe w znaczącej przewadze nieakceptujące tej propozycji rozwiązań zdecydowanie opowiedziało się za jej odrzuceniem. I choć nowelą z 2011 r. tę drogę awansu naukowego utrzymano, postępowanie habilitacyjne uproszczono i skrócono (w porównaniu z rozwiązaniami wcześniejszymi), poddając jego przebieg głównie procedurze pisemnej ${ }^{10}$.

W okresie objętym analizą (1990-2017) obraz prawnej regulacji przewodów/postępowań habilitacyjnych podlegał więc zmianom

\footnotetext{
${ }^{9}$ W odniesieniu do szkół wyższych zob. art. 2 ust. 1 Ustawy z dnia 12 IX 1990 r. o szkolnictwie wyższym (Dz.U. Nr 65, poz. 385), zgodnie z którym „[s]zkoły wyższe [...] są organizowane i działają na zasadzie wolności badań naukowych, wolności twórczości artystycznej". Podobne rozwiązania przyjęła także Ustawa z dnia 27 VII 2005 r. Prawo o szkolnictwie wyższym (Dz.U. Nr 164, poz. 1365 ze zm.). W myśl jej art. 4 ust. 2 i 3 "[u]czelnie kierują się zasadami wolności [...] badań naukowych i twórczości artystycznej", a poprzez prowadzenie badań naukowych mają pełnić misję odkrywania i przekazywania prawdy. Nie bez znaczenia dla polityki naukowej i programów badań naukowych oraz warunków ich finansowania było również wdrożenie Ustawy z dnia 12 I 1991 r. o Komitecie Badań Naukowych (Dz.U. Nr 8, poz. 28 ze zm.).

${ }^{10} \mathrm{O}$ wątpliwościach dotyczących skali nowelizowanych zmian ustawowych z $2011 \mathrm{r}$. oraz jej skutków oraz o tym, na ile dla wielu osób zmiany mogą się okazać niespełnieniem ich oczekiwań, zob. M. Chałupka, Prawo o szkolnictwie wyższym z komentarzem ( $z$ uwzględnieniem zmian obowiązujących od października 2011 r.), Warszawa 2011, s. 8.
} 
w różnym stopniu i zakresie. Rzeczą do ustalenia jest zatem zbadanie, z wykorzystaniem metody dogmatyczno-prawnej, znaczenia wprowadzonych pod rządami obu ustaw rozwiązań w zakresie dotyczącym: (1) dziedzin nauki i dyscyplin naukowych, w jakich mogły być nadawane stopnie naukowe; (2) wymagań stawianych przed ówczesnymi szkołami wyższymi i innymi jednostkami organizacyjnymi ubiegającymi się o nabycie uprawnienia do ich przeprowadzania; (3) tego, w jakim stopniu i zakresie zmianom $\mathrm{w}$ tych latach podlegały warunki przeprowadzania habilitacji oraz co za ich wprowadzeniem przemawiało. Nie mniej istotne jest także uzupełnienie badań o ustalenie (4) zakresu środków ochrony prawnej przysługującej kandydatowi do tego stopnia naukowego w przypadku negatywnego rozstrzygania na poszczególnych etapach prowadzonego przewodu/postępowania habilitacyjnego, włącznie z odmową (do 2005 r.) zatwierdzenia uchwały rady o nadaniu stopnia naukowego doktora habilitowanego.

Zachowanie odrębnych od prawa szkolnictwa wyższego ustaw z 1990 i 2003 r. w zakresie stopni naukowych w żadnym razie nie wyłączało kompetencji właściwego ministra (od 1987 r. Ministra Edukacji Narodowej ${ }^{11}$, od 1999 r. Ministra Nauki ${ }^{12}$, od 2001 r. Ministra Edukacji Narodowej i Sportu ${ }^{13}$, od 2003 r. Ministra Nauki i Informaty-

${ }^{11}$ Ustawa z dnia 23 X 1987 r. o utworzeniu urzędu Ministra Edukacji Narodowej (Dz.U. Nr 33, poz. 178 ze zm.), którą zniesiono urząd Ministra Nauki i Szkolnictwa Wyższego (art. 7). Ustawę tę uchylono z dniem 1 IV 1999 r. nowelizacją Ustawy z dnia 4 IX 1997 r. o działach administracji rządowej (Dz.U. Nr 141, poz. 943 ze zm.). Zob. też wykaz jednostek organizacyjnych, w tym poddanych nadzorowi Ministra Edukacji Narodowej szkół wyższych, objęty załącznikiem do Rozporządzenia Rady Ministrów z dnia 22 XI 1994 r. w sprawie nadania statutu Ministerstwu Edukacji Narodowej (Dz.U. Nr 126, poz. 616).

${ }^{12}$ Od 19 X 1999 r. pełnienie urzędu Ministra Nauki łączono z funkcją Przewodniczącego Komitetu Badań Naukowych. Zob. też art. 1 pkt 19 Ustawy z dnia 24 VII 1999 r. o zmianie ustawy o działach administracji rządowej oraz niektórych innych ustaw (Dz.U. Nr 70, poz. 778) oraz Rozporządzenie Rady Ministrów z dnia 26 III 2002 r. w sprawie szczegółowego zakresu działania Ministra Nauki (Dz.U. Nr 96, poz. 852 ze zm.). Obsługę tegoż ministra zapewniał Urząd Komitetu Badań Naukowych.

${ }^{13}$ Rozporządzenie Rady Ministrów z dnia 3 XI 1999 r. w sprawie utworzenia Ministerstwa Edukacji Narodowej (Dz.U. Nr 91, poz. 1019), od 2001 r. na mocy Rozporządzenia Rady Ministrów z dnia 20 X 2001 r. zmieniającego rozporządzenie w sprawie utworzenia Ministerstwa Edukacji Narodowej (Dz.U. Nr 122, poz. 1328) ze zmienioną nazwą - Ministerstwo Edukacji Narodowej i Sportu, oraz Rozporządzenie Prezesa Rady Ministrów z dnia 1 VII 2002 r. w sprawie szczegółowego zakresu działania Ministra Edukacji Narodowej i Sportu (Dz.U. Nr 97, poz. 866 ze zm.); Rozporządzenie Prezesa Rady Ministrów z dnia 4 V 2004 r. w sprawie szczegółowego zakresu działania Ministra Edukacji Narodowej i Sportu (Dz.U. Nr 106, poz. 1118); Rozporządzenie Prezesa Rady 
zacji $^{14}$, od 2005 r. Ministra Edukacji i Nauki ${ }^{15}$, od 2006 r. Ministra Nauki i Szkolnictwa Wyższego ${ }^{16}$ ) od spraw dotyczących awansów naukowych, aczkolwiek zakres działań właściwego ministra w tych latach podlegał również zmianom i w różnym stopniu znajdował odniesienie wprost do nadawania stopni naukowych. Rozwiązaniem nowym było także znaczne ograniczenie udziału w przewodach/postępowaniach na stopień naukowy Rady Głównej Szkolnictwa Wyższego (od 2011 r. Rady Głównej Nauki i Szkolnictwa Wyższego) oraz nadanie Centralnej Komisji (od 1990 r. do Spraw Tytułu Naukowego i Stopni Naukowych, od 2003 r. do Spraw Stopni i Tytułów) nowej, szerszej roli i zadań.

Ministrów z dnia 11 VI 2004 r. w sprawie szczegółowego zakresu działania Ministra Edukacji Narodowej i Sportu (Dz.U. Nr 134, poz. 1426); Rozporządzenie Rady Ministrów z dnia 23 VIII 2005 r. w sprawie utworzenia Ministerstwa Edukacji Narodowej oraz zniesienia Ministerstwa Edukacji Narodowej i Sportu (Dz.U. 165, poz. 1367).

${ }^{14}$ Rozporządzenie Prezesa Rady Ministrów z dnia 18 III 2003 r. w sprawie utworzenia Ministerstwa Nauki i Informatyzacji i zniesienia urzędu Komitetu Badań Naukowych (Dz.U. Nr 51, poz. 443) oraz dwa rozporządzenia Prezesa Rady Ministrów o jednobrzmiącym tytule - w sprawie szczegółowego zakresu działania Ministra Nauki i Informatyzacji: z dnia 4 V 2004 r. (Dz.U. Nr 106, poz. 1123 ze zm.) i z dnia 11 VI 2004 r. (Dz.U. Nr 134, poz. 1431).

${ }^{15}$ Rozporządzenie Rady Ministrów z dnia 31 X 2005 r. w sprawie utworzenia Ministerstwa Edukacji i Nauki oraz zniesienia Ministerstwa Edukacji Narodowej i Informatyzacji (Dz.U. Nr 220, poz. 1879) oraz Rozporządzenie Prezesa Rady Ministrów z dnia 31 X 2005 r. w sprawie szczegółowego zakresu działania Ministerstwa Edukacji i Nauki (Dz.U. Nr 220, poz. 1886). Ministerstwo to zniesiono mocą Rozporządzenia Rady Ministrów z dnia 5 V 2006 r. w sprawie utworzenia Ministerstwa Edukacji Narodowej oraz zniesienia Ministerstwa Edukacji i Nauki (Dz.U. Nr 76, poz. 532).

${ }^{16}$ Rozporządzenie Rady Ministrów z dnia 5 V 2006 r. w sprawie utworzenia Ministerstwa Nauki i Szkolnictwa Wyższego (Dz.U. Nr 76, poz. 533 ze zm.). Zob. także: Rozporządzenie Prezesa Rady Ministrów z dnia 5 V 2006 r. w sprawie szczegółowego zakresu działania Ministra Nauki i Szkolnictwa Wyższego (Dz.U. Nr 76, poz. 540); Rozporządzenie Prezesa Rady Ministrów z dnia 18 VII 2006 r. w sprawie szczegółowego zakresu działania Ministra Nauki i Szkolnictwa Wyższego (Dz.U. Nr 131, poz. 912); Rozporządzenie Prezesa Rady Ministrów z dnia 16 XI 2007 r. w sprawie szczegółowego zakresu działania Ministra Nauki i Szkolnictwa Wyższego (Dz.U. Nr 216, poz. 1596); Rozporządzenie Prezesa Rady Ministrów z dnia 16 III 2011 r. w sprawie szczegółowego zakresu działania Ministra Nauki i Szkolnictwa Wyższego (Dz.U. Nr 63, poz. 324); Rozporządzenie Prezesa Rady Ministrów z dnia 18 XI 2011 r. w sprawie szczegółowego zakresu działania Ministra Nauki i Szkolnictwa Wyższego (Dz.U. Nr 248, poz. 1483); Rozporządzenie Prezesa Rady Ministrów z dnia 22 IX 2014 r. w sprawie szczegółowego zakresu działania Ministra Nauki i Szkolnictwa Wyższego (Dz.U. poz. 1259); Rozporządzenie Prezesa Rady Ministrów z dnia 17 XI 2015 r. w sprawie szczegółowego zakresu działania Ministra Nauki i Szkolnictwa Wyższego (Dz.U. poz. 1896); Rozporządzenie Prezesa Rady Ministrów z dnia 13 XII 2017 r. w sprawie szczegółowego zakresu działania Ministra Nauki i Szkolnictwa Wyższego (Dz.U. poz. 2317 ze zm.). 


\section{Uprawnienia do habilitowania}

W ślad za ustawą z 1965 r. ustawami z 1990 i 2003 r. prawo do przeprowadzania przewodów habilitacyjnych zachowano dla: jednostek organizacyjnych - szkół wyższych ${ }^{17}$, placówek naukowych Polskiej Akademii Nauk oraz instytutów badawczo-rozwojowych (od 2010 r. instytutów badawczych). Oczywiście, wdrożeniu pierwszej z tych ustaw (i dalszemu obowiązywaniu ustaw dotyczących placówek naukowych PAN ${ }^{18}$ oraz instytutów badawczych ${ }^{19}$ ) nie od razu towarzyszyło zwiększenie potencjału jednostek organizacyjnych dotąd uprawnionych do nadawania wyższego stopnia naukowego. Stosownie do rzeczywistości ówcześnie kreowanej ich liczba w kolejnych latach podlegała ewolucyjnie wdrażanym zmianom. Podobnie ewolucyjny charakter cechował zmiany w zakresie warunków wymaganych do otrzymania uprawnienia do przeprowadzania przewodów habilitacyjnych. Rewizji poddawano dziedziny nauki i dyscypliny naukowe, $w$ jakich mogły być nadawane stopnie naukowe, oraz ich wykazy legitymizujące szkoły wyższe i inne jednostki organizacyjne poza szkołami wyższymi do nadawania stopnia naukowego doktora habilitowanego. Dopiero rok 2011 wprowadził w tym zakresie dalej idące zmiany. Ustawą nowelizującą wdrożono nie tylko nowe wymagania stawiane przed jednostkami organizacyjnymi wnioskującymi o nabycie uprawnienia do prowadzenia postępowań habilitacyjnych, ale i zmienione warunki oraz tryb ich przebiegu. Wprowadzono wykazy obszarów wiedzy, dziedzin nauki i dyscyplin naukowych. Odstąpiono od publikowania w urzędowym dzienniku promulgacyjnym kolejnych wykazów szkół wyższych i innych jednostek organizacyjnych uprawnionych do nadawania stopnia naukowego doktora habilitowanego.

17 Także dla samodzielnych placówek typu naukowo-dydaktycznego utworzonych przed dniem wejścia w życie Ustawy z dnia 12 IX 1990 r. o szkolnictwie wyższym. Zgodnie z jej art. 203 placówki te mogły nadal działać na podstawie nadanych im statutów. Ich zmiany mógł dokonać właściwy minister. On też mógł placówki te przekształcać, łączyć i znosić. Tej ani zbliżonej treści nie powtórzyła Ustawa z dnia 27 VII 2005 r. Prawo o szkolnictwie wyższym.

${ }^{18}$ Ustawa z dnia 17 II 1960 r. o Polskiej Akademii Nauk (Dz.U. Nr 10, poz. 64), uchylona Ustawą z dnia 25 IV 1997 r. o Polskiej Akademii Nauk (Dz.U. Nr 75, poz. 469). Tę ustawę uchylono Ustawą z dnia 30 IV 2010 r. Przepisy wprowadzające ustawy reformujące system nauki (Dz.U. Nr 96, poz. 620). Nadal obowiązująca jest Ustawa z dnia 30 IV 2010 r. o Polskiej Akademii Nauk (Dz.U. Nr 96, poz. 619).

${ }^{19}$ Miała tu zastosowanie Ustawa z dnia 25 VII 1985 r. o jednostkach badawczo-rozwojowych (Dz.U. Nr 36, poz. 170 ze zm.), a obecnie ma zastępująca ją Ustawa z dnia 30 IV 2010 r. o instytutach badawczych (Dz.U. Nr 96, poz. 618). 
Wdrożone pod rządami obu ustaw rozwiązania i ich zmiany w żadnym razie nie burzyły generalnie zakreślonego zakresu podmiotowego. Z istoty rzeczy jego zachowanie nie mogło jednak oznaczać i nie oznaczało prawa każdej z ówczesnych jednostek organizacyjnych do habilitowania i nadawania stopnia naukowego doktora habilitowanego. Uprawnienia w tym zakresie mogły na swój wniosek uzyskać tylko te z nich, które: (1) w zakresie danej dziedziny nauki i dyscypliny naukowej - gdy je określono ${ }^{20},(2)$ spełniały prawem zakreślone wymagania i były (3) objęte wykazem jednostek uprawnionych do nadawania stopnia naukowego doktora habilitowanego.

\subsection{Stopnie naukowe a dziedziny nauki i dyscypliny naukowe}

Zarówno przed rokiem 1990, jak i po nim wyższy stopień naukowy nie od razu był nadawany w dziedzinach nauki oraz w dyscyplinach naukowych. Począwszy od roku 1965, stopień naukowy docenta (od 1968 r. doktora habilitowanego ${ }^{21}$ ) mógł być nadawany wyłącznie w szesnastu dziedzinach nauki, w roku 1974 katalog ten rozszerzono do dwudziestu dziedzin nauki ${ }^{22}$. Dopiero od roku 1986 filozofię tę częściowo zmieniono. Odtąd powrócono do szesnastu dziedzin nauki, dziesięciu z nich przypisując dyscypliny naukowe (w liczbie zróżnicowanej od dwóch do dziesięciu), dla pozostałych sześciu dziedzin rezygnując z określenia dyscyplin naukowych. I ten stan prawny zachowano do czasu wdrożenia wydanych na mocy ustawy z 1990 r. przepisów wykonawczych. Nie był to pośpieszny czas zmian. Zgodnie z art. 45 ustawy z $1990 \mathrm{r}$. pozostawały bowiem w mocy przepisy dotychczasowe aktów wykonawczych, o ile nie były sprzeczne z jej przepisami, nie dłużej jednak niż do dnia 31 marca 1991 r. Tym samym mocą tej ustawy, do czasu nowych uregulowań, zachowano moc obowiązującą dotychczasowego Zarządzenia Ministra Nauki

${ }^{20}$ Dla dziedzin nauki, dla których nie wprowadzono dyscyplin naukowych, nie trudno przyjąć, że wobec nich mają zastosowanie postanowienia art. 1 ust. 2 ustawy pierwszej i art. 3 ust. 1 ustawy drugiej jednobrzmiąco przyjmujące, że "[d]yscyplina naukowa (artystyczna) może być tożsama z dziedziną nauki (sztuki)".

${ }^{21}$ Zob. art. 1 pkt 5 Ustawy z dnia 20 XII 1968 r. o zmianie ustawy o stopniach naukowych i tytułach naukowych (Dz.U. Nr 46, poz. 335).

${ }^{22}$ Zob. Zarządzenie Ministra Nauki, Szkolnictwa Wyższego i Techniki z dnia 16 VII 1974 r. zmieniające zarządzenie w sprawie bliższego określenia stopni naukowych i tytułów naukowych w zależności od dziedziny nauki lub dyscypliny naukowej, których te stopnie dotyczą (M.P. Nr 27, poz. 161). 
i Szkolnictwa Wyższego z dnia 18 czerwca 1986 r. w sprawie dziedzin nauki i dyscyplin naukowych, w zakresie których mogły być nadawane stopnie naukowe ${ }^{23}$. Tymczasem nowy wykaz dziedzin nauki lub sztuki oraz dyscyplin naukowych (artystycznych) określony uchwałą Centralnej Komisji do Spraw Tytułu Naukowego i Stopni Naukowych z dnia 16 grudnia $1991 \mathrm{r}^{24}$ ogłoszono obwieszczeniem tej Komisji z dnia 25 lutego $1992 \mathrm{r}^{25}$, z datą jego wejścia w życie z dniem 11 czerwca 1992 r., a zatem znaczniej później, aniżeli przewidywała to ustawa. Nie jest więc jasne, w obrębie jakich dziedzin nauki oraz dyscyplin naukowych w okresie wyznaczonym art. 45 ustawy a terminem wejścia w życie i obowiązywania wydanego na jej podstawie (art. 1 ust. 2 i art. 5 ust. 1) Obwieszczenia Przewodniczącego Centralnej Komisji z dnia 25 lutego 1992 r. nadawano stopień naukowy doktora habilitowanego. Wykazem tym objęto dwadzieścia jeden dziedzin nauki, dla dwunastu z nich przewidując dyscypliny naukowe (od dwóch do dziewiętnastu), dla dziewięciu dziedzin nauki rezygnując z wprowadzenia dyscyplin naukowych ${ }^{26}$. Blisko rok później,

${ }^{23}$ W odniesieniu do habilitacji zob. Zarządzenie Ministra Edukacji Narodowej z dnia 10 VI 1989 r. zmieniające zarządzenie w sprawie dziedzin nauki i dyscyplin naukowych, w zakresie których mogą być nadawane stopnie naukowe, oraz bliższego określenia stopni naukowych i tytułów naukowych (M.P. Nr 12, poz. 98 ze zm.).

${ }^{24}$ Uchwała niepublikowana.

${ }^{25}$ M.P. Nr 16, poz. 123. Zob. też Obwieszczenie Przewodniczącego Rady Wyższego Szkolnictwa Artystycznego z dnia 20 VII 1991 r. w sprawie wykazu dziedzin nauki i dyscyplin artystycznych, w zakresie których mogą być przeprowadzane przewody kwalifikacyjne I i II stopnia (M.P. Nr 27, poz. 198 ze zm.), uchylone Obwieszczeniem Przewodniczącego Rady Wyższego Szkolnictwa Artystycznego z dnia 17 XII 2002 r. w sprawie wykazu dziedzin sztuki i dyscyplin artystycznych, w zakresie których mogą być przeprowadzane przewody kwalifikacyjnego I i II stopnia (M.P. Nr 13, poz. 197).

${ }^{26}$ Wykazem objęto następujące dziedziny nauki - z dyscyplinami naukowymi, tam gdzie je przewidziano, podanymi w nawiasie: nauki biologiczne (biochemia; biologia; biotechnologia; ekologia); nauki chemiczne (biochemia; chemia; technologia chemiczna); nauki ekonomiczne (ekonomia; nauki o zarządzaniu; towaroznawstwo); nauki farmaceutyczne; nauki fizyczne (astronomia; biofizyka; fizyka; geofizyka); nauki humanistyczne (archeologia; bibliologia; etnologia; filozofia; historia; językoznawstwo; literaturoznawstwo; nauki o polityce; nauki o poznaniu i komunikacji; nauki o sztuce; nauki o zarządzaniu; pedagogika; psychologia; socjologia); nauki leśne (drzewnictwo; leśnictwo); nauki matematyczne (informatyka; matematyka); nauki medyczne (biologia medyczna; medycyna; stomatologia); nauki o kulturze fizycznej; nauki o ziemi (geofizyka; geografia; geologia; oceanologia); nauki prawne (nauka o administracji; prawo; prawo kanoniczne); nauki rolnicze (agronomia; inżynieria rolnicza; kształtowanie środowiska; ogrodnictwo; rybactwo; technologia żywności i żywienia; zootechnika); nauki techniczne (architektura i urbanistyka; automatyka i robotyka; biocybernetyka i inżynieria biomedyczna; budowa i eksploatacja maszyn; budownictwo; elektronika; elektrotechnika; geodezja i kartografia; górnictwo; informatyka; inżynieria chemiczna; inżynieria 
zgodnie z art. 5 ust. 1 ustawy oraz niepublikowanymi uchwałami Centralnej Komisji do Spraw Tytułu Naukowego i Stopni Naukowych z dnia 25 stycznia i 22 lutego 1993 r., Przewodniczący tejże Komisji swym obwieszczeniem z dnia 23 lutego 1993 r. ogłosił jego zmianę ${ }^{27}$. Zmianą tac dwóm dziedzinom nauki (nauki biologiczne oraz nauki humanistyczne) dodano odpowiednio po jednej dyscyplinie naukowej (biofizykę - nauki biologiczne, religioznawstwo - nauki humanistyczne).

Obwieszczenie Centralnej Komisji z dnia 25 lutego 1992 r. uchylono 14 sierpnia 2003 r. z dniem wejścia w życie ${ }^{28}$ Uchwały Centralnej Komisji do Spraw Stopni i Tytułów z dnia 23 czerwca 2003 r. ${ }^{29}$, wydanej na podstawie art. 3 ust. 1 kolejno wdrożonej ustawy o stopniach naukowych i tytule naukowym oraz o stopniach i tytule w zakresie sztuki. Mocą tej uchwały (choć można mieć wątpliwości, czy wobec uchwalenia Konstytucji RP w $1997 \mathrm{r} .{ }^{30}$ forma uchwały jako aktu prawnego nieobowiązującego powszechnie powinna być tu, jak i w kolejnych latach przyjęta) zachowano dotychczasową liczbę dwudziestu jeden dziedzin nauki i wyróżnienie ich nazw, dla siedmiu z nich nie przewidując dyscyplin naukowych. Dla dwóch z dziewięciu dotychczasowych dziedzin nauki (sztuki muzyczne oraz sztuki plastyczne) po raz pierwszy wprowadzono dyscypliny naukowe ${ }^{31}$. I tego stanu prawnego wiele nie zmieniła kolejna uchwała Centralnej Komisji do Spraw Stopni i Tytułów z dnia 24 października 2005 r. ${ }^{32}$ Przy niezmienionym od roku 1992 wykazie liczby i nazw dziedzin nauki rozszerzono nią niektóre z nich o kolejne

materiałowa; inżynieria środowiska; mechanika; metalurgia; technologia chemiczna; telekomunikacja; transport; włókiennictwo; nauki teologiczne; nauki weterynaryjne; nauki wojskowe; sztuki filmowe; sztuki muzyczne; sztuki plastyczne; sztuki teatralne.

${ }^{27}$ Obwieszczenie Przewodniczącego Centralnej Komisji do spraw Tytułu Naukowego i Stopni Naukowych z dnia 23 II 1993 r. w sprawie zmiany wykazu nauki i sztuki oraz dyscyplin naukowych i artystycznych, w zakresie których mogą być nadawane stopnie naukowe (M.P. Nr 10, poz. 71). Obwieszczenie to weszło w życie z dniem 13 III 1993 r.

${ }^{28}$ Na podstawie art. 53 ustawy z dnia 14 III $2003 \mathrm{r}$.

${ }^{29}$ M.P. $2003 \mathrm{Nr}$ 40, poz. 586.

${ }^{30}$ Zob. art. 87 Konstytucji Rzeczypospolitej Polskiej z dnia 2 IV 1997 r. (Dz.U. Nr 78, poz. 483 ze zm.).

${ }^{31} \mathrm{~W}$ skład pierwszej z dziedzin nauki (sztuki muzyczne) weszły następujące dyscypliny naukowe: dyrygentura, instrumentalistyka, kompozycja i teoria muzyki, reżyseria dźwięku, rytmika i taniec, wokalistyka. Z kolei drugą z dziedzin (nauki plastyczne) objęto dyscypliny: architektura wnętrz, fotografia, grafika, konserwacja dzieł sztuki, malarstwo, rzeźba, wzornictwo.

${ }^{32}$ Uchwała Centralnej Komisji do Spraw Stopni i Tytułów z dnia 24 X 2005 r. w sprawie określenia dziedzin nauki i dziedzin sztuki oraz dyscyplin naukowych i artystycznych (M.P. Nr 79, poz. 1120). 
dyscypliny naukowe, tj. o: mikrobiologię w zakresie nauk biologicznych; biotechnologię w zakresie nauk chemicznych; historię sztuki, językoznawstwo w zakresie nauk humanistycznych; górnictwo i geologię inżynierską w zakresie nauk technicznych. W roku $2008^{33}$ rozszerzono liczbę dziedzin nauki o nauki o zdrowiu (bez określenia dyscyplin naukowych) oraz dodano dyscypliny naukowe - biotechnologię w dziedzinie nauk rolniczych i energetykę - w dziedzinie nauk technicznych; zastąpiono dotychczasową nazwę dyscypliny artystycznej - sztuki użytkowe dyscypliną nową - sztuki projektowe, dodając zarazem dyscyplinę kolejną - konserwacja i restauracja dzieł sztuki. Dwa lata później mocą uchwały Centralnej Komisji z dnia 23 kwietnia 2010 r. ${ }^{34}$ trzy dziedziny nauki rozszerzono o kolejne dyscypliny naukowe: finanse $\mathrm{w}$ dziedzinie nauk ekonomicznych, bibliologię i informatologię (w miejsce dotychczasowej bibliologii) w dziedzinie nauk humanistycznych oraz inżynierię produkcji w dziedzinie nauk technicznych. Niecały rok później uchwałą Centralnej Komisji z dnia 28 stycznia 2011 r. ${ }^{35}$ w dziedzinie nauk humanistycznych dodano dwie dalsze dyscypliny naukowe (nauki o bezpieczeństwie oraz nauki o obronności), odstępując zarazem od dziedziny naukowej - nauki wojskowe.

W efekcie przyjętych wówczas rozwiązań przed wdrożeniem w roku 2011 nowelizacji ustawy z dnia 14 marca 2003 r. stopnie naukowe mogły być nadal nadawane $\mathbf{w}$ dwudziestu jeden dziedzinach nauki oraz w dziewięćdziesięciu pięciu dyscyplinach naukowych.

Wdrożenie w roku 2011 nowelizacji ustawy z 2003 r. przyniosło rewolucyjne w tym zakresie rozwiązania. Po pierwsze, zmienił się organ właściwy - już nie Centralna Komisja, lecz minister właściwy do spraw szkolnictwa wyższego (i słusznie) po zasięgnięciu opinii Centralnej Komisji; po drugie, forma prawna, w jakiej mogły być określone dziedziny nauki i sztuki oraz dyscypliny naukowe i artystyczne - $\mathrm{w}$ drodze

${ }^{33}$ Uchwała Centralnej Komisji do Spraw Stopni i Tytułów z dnia 10 XII 2008 r. zmieniająca uchwałę w sprawie określenia dziedzin nauki i dziedzin sztuki oraz dyscyplin naukowych i artystycznych (M.P. Nr 87, poz. 843).

${ }^{34}$ Uchwała Centralnej Komisji do Spraw Stopni i Tytułów z dnia 23 IV 2010 r. zmieniająca uchwałę w sprawie określenia dziedzin nauki i dziedzin sztuki oraz dyscyplin naukowych i artystycznych (M.P. Nr 46, poz. 636).

${ }^{35}$ Uchwała Centralnej Komisji do Spraw Stopni i Tytułów z dnia 28 I 2011 r. zmieniająca uchwałę w sprawie określenia dziedzin nauki i dziedzin sztuki oraz dyscyplin naukowych i artystycznych (M.P. Nr 14, poz. 149). Uchwałę tę uchylono Ustawą z dnia 18 III 2011 r. o zmianie ustawy Prawo szkolnictwa wyższego i innych ustaw (Dz.U. Nr 84, poz. 455). 
rozporządzenia (i to także trafne rozwiązanie); po trzecie, podkreślono potrzebę uwzględnienia rozwoju dziedzin nauki i dziedzin sztuki i odpowiednio dyscyplin naukowych i artystycznych, w jakich stopnie naukowe mogły być nadawane, a obszary wiedzy z obszarami kształcenia - przewidzianymi przepisami o szkolnictwie wyższym. W ten sposób założono pewną stabilność prawnych rozwiązań w tym zakresie, bez uszczerbku dla rozwoju dziedzin nauki i dyscyplin naukowych (artystycznych). I tak w istocie się stało. Minister Nauki i Szkolnictwa Wyższego rozporządzeniem z dnia 8 sierpnia 2011 r. ${ }^{36}$ określiła osiem obszarów wiedzy (nauki: humanistyczne; społeczne; ścisłe; przyrodnicze; techniczne; rolnicze, leśne i weterynaryjne; medyczne i nauki o zdrowiu oraz nauki o kulturze fizycznej; sztuki), dwadzieścia dwie dziedziny nauki (humanistyczne, teologiczne - co było rozwiązaniem nowym, społeczne, ekonomiczne, prawne, matematyczne, fizyczne, chemiczne, biologiczne, nauki o Ziemi, techniczne, rolnicze, leśne, weterynaryjne, medyczne, farmaceutyczne, nauki o zdrowiu, nauki o kulturze, sztuk filmowych, sztuk muzycznych, plastycznych, teatralnych) oraz dziewięćdziesiąt cztery dyscypliny naukowe $i$ artystyczne. W istocie od rozwiązań przyjętych przed nowelizacją z 2011 r. zmiany wprowadzone po tej dacie nie są propozycją kreatywna, poza wprowadzeniem obszarów wiedzy oraz zmianą przyporządkowania niektórych dyscyplin naukowych do dziedzin nauki ${ }^{37}$. Wyraźnie jednak odbiegały

${ }^{36}$ Rozporządzenie Ministra Nauki i Szkolnictwa Wyższego z dnia 8 VIII 2011 r. w sprawie obszarów wiedzy, dziedzin nauki i sztuki oraz dyscyplin naukowych i artystycznych (Dz.U. Nr 179, poz. 1065). Rozporządzenie to uchylono Ustawą z dnia 3 VII 2018 r. Przepisy wprowadzające ustawę Prawo o szkolnictwie wyższym i nauce (Dz.U. poz. 1669 ze zm.).

${ }^{37}$ Rozbudowano dziedzinę nauk społecznych o nowe dla tej dziedziny dyscypliny, przeniesione $\mathrm{z}$ dziedziny nauk humanistycznych: nauki o obronności, nauki o bezpieczeństwie, nauki o polityce, pedagogikę, psychologię, socjologię, a także nauki o poznaniu i komunikacji społecznej - dając tym samym nową pojemność dziedzinie nauk społecznych. Ponadto dodano do niej dwie dyscypliny: nauki o mediach i nauki o polityce publicznej. Dziedzinę nauk humanistycznych uzupełniono o dyscyplinę - nauki o rodzinie. Zmiany w tym zakresie bez wątpienia nie pozostawały bez znaczenia dla właściwych rad jednostek organizacyjnych posiadających uprawnienie do nadawania stopni naukowych, w tym doktora habilitowanego, otrzymane przed wprowadzeniem w tym zakresie zmian. Dziedzinami nauki, dla których nadal nie wyodrębniono dyscyplin naukowych, były: nauki farmakologiczne, nauki o zdrowiu, o kulturze fizycznej, teologiczne, weterynaryjne oraz sztuki teatralne i filmowe. W tej sytuacji od $1990 \mathrm{r}$. przyjęto rozwiązanie, zgodnie z którym dyscyplina naukowa (artystyczna) mogła być tożsama z dziedziną nauki lub dziedziną sztuki (art. 1 ust. 2 ustawy z 1990 r., art. 3 ust. 1 ustawy z 2003 r.). Szerzej zob. H. Izdebski, J. Zieliński, Komentarz do art. 3, w: iidem, Prawo 
od dwustopniowej kwalifikacji nauk opartej na systematyce przyjętej przez Organizację Współpracy Gospodarczej i Rozwoju (OECD), a polegającej na wyodrębnieniu sześciu dziedzin nauki (przyrodnicze, inżynieryjne i techniczne, medyczne i nauki o zdrowiu, rolnicze, społeczne, humanistyczne oraz sztuki $)^{38}$. Tego stanu prawnego nie zmieniono do czasu utraty mocy obowiązującej ustawy z $2003 \mathrm{r}^{39}$

\subsection{Wymagania w zakresie uprawnienia do nadawania stopnia naukowego doktora habilitowanego}

Ustawodawca dość ogólnie przyjął, że stopnie naukowe są nadawane w jednostkach organizacyjnych szkół wyższych oraz w innych placówkach naukowych (art. 2 ustawy z 1990 r.), w jednostkach organizacyjnych (art. 5 ust. 2 ustawy z 2003 r.) - które posiadają uprawnienie do ich nadawania. Tego ogólnego założenia nie niweczyły postanowienia art. 40 ust. 1 ustawy pierwszej ani art. 49 ust. 1 ustawy drugiej - zachowujące uprawnienia jednostek organizacyjnych do nadawania stopni naukowych otrzymane na podstawie przepisów dotychczasowych, jeżeli te spełniały wymagania określone ustawa z $1990 \mathrm{r}$. i odpowiednio ustawa z 2003 r. Zastrzeżenie to, w obu ustawach o jednobrzmiącej treści, dla oceny zachowania przez jednostki organizacyjne ich dotychczasowych uprawnień miało różny walor. Dla otrzymania uprawnienia do nadawania stopnia doktora habilitowanego zgodnie z ustawą pierwszą stawiano skromniej określone wymagania aniżeli te, na podstawie których jednostki te otrzymały uprawnienia określone przez dotychczasowe przepisy. Ustawa ta sprowadziła je do tzw. minimum kadrowego oraz poziomu działalności naukowej (działalności artystycznej) jednostki. O ile warunek pierwszy był określony ustawą jednoznacznie, o tyle zabrakło zdefiniowania drugiego z wymagań, jasno określonego przed wejściem w życie ustawy z 1990 r. ${ }^{40} \mathrm{~W}$ innej sytuacji znalazły się nato-

o szkolnictwie wyższym. Ustawa o stopniach naukowych i tytule naukowym. Komentarz do nowelizacji, Warszawa 2011, s. 409-410.

${ }^{38}$ Klasyfikacja dziedzin nauki i techniki według OECD, https://www.ncbr.gov.pl/ fileadmin/user_upload/import/tt_content/files/2_wykaz_dziedzin_nauki_i_technik_wedlug_klasyfikacji_oecd.pdf (dostęp: 31 VIII 2019).

${ }^{39}$ Ustawę tę uchylono z dniem 1 X 2018 r. na mocy Ustawy z dnia 3 VII 2018 r. Przepisy wprowadzające ustawę - Prawo o szkolnictwie wyższym i nauce.

${ }^{40}$ Zgodnie z ustawą z 1965 r. w brzmieniu nadanym jej w 1985 r. tekstem jednolitym (Obwieszczenie Ministra Nauki i Szkolnictwa Wyższego z dnia 11 IX 1985 r. w sprawie ogłoszenia jednolitego tekstu ustawy z dnia 31 III 1965 r. o stopniach naukowych 
miast jednostki organizacyjne, które na mocy ustawy z 2003 r. mogły zachować wcześniej otrzymane uprawnienie. Wymagania dla otrzymania uprawnienia do nadawania stopnia doktora habilitowanego pod rządami tej ustawy były jasne i zakreślone. Ta dysproporcja obecna w obu ustawach co do podstawy uznania uprawnień do nadawania stopni naukowych na podstawie dotychczasowych przepisów nie pozostawała także bez znaczenia dla osób, którym w oparciu o nie nadano stopień naukowy doktora habilitowanego. Ustawa z 1990 r. w art. 41 ust. 1 przewidywała, że "stopnie doktora habilitowanego, uzyskane na podstawie dotychczasowych przepisów stają się [...] stopniami naukowymi doktora habilitowanego, określonymi w niniejszej ustawie". Ustawa z 2003 r., w jej pierwotnym brzmieniu, tej treści postanowienia już nie powtórzyła.

Dla jednostek organizacyjnych po raz pierwszy ubiegających się o otrzymanie uprawnienia do nadawania stopnia doktora habilitowanego wymagania określone ustawami z 1990 i 2003 r. bez wątpienia miały konstytutywny charakter. I w tym ujęciu ich sytuacja była zdecydowanie odmienna. Od nich zarówno pierwsza, jak i druga ustawa wymagały złożenia wniosku, z jednym - przyjętym wyłącznie ustawą z 1990 r. - zastrzeżeniem, że nierozpatrzone do dnia jej wejścia w życie wnioski o przyznanie uprawnienia do nadawania stopni naukowych rozpatruje się na podstawie przepisów tejże ustawy (art. 40 ust. 2). I nie były to jedyne różnice. Do określenia trybu zgłaszania wniosków ustawa z 1990 r. zobowiązała Przewodniczącego Centralnej Komisji (art. 5 ust. 2), ustawa z 2003 r. - ministra właściwego do spraw szkolnictwa wyższego (art. 7 ust. 1). Pod rządami ustawy pierwszej przewodniczący Centralnej Komisji żadnej z kadencji przypadających na okres jej obowiązywania tego trybu nie określił. Co w żadnym razie nie mogło rodzić podstawy do uznania, że jednostki organizacyjne są pozbawione prawa złożenia wniosku w tym zakresie. Naruszałoby to ich ustawowe prawo. Wnioskodawca mógł zatem kierować się przesłankami podanymi w ustawie, a Centralna Komisji nie miała podstaw do odrzucenia jego

\footnotetext{
i tytułach naukowych - Dz.U. Nr 42, poz. 202) od jednostek organizacyjnych ubiegających się o otrzymanie uprawnienia do nadawania stopnia naukowego doktora habilitowanego wymagano ponadto wykazania się: (1) osiągnięciami w pracy naukowej w zakresie określonej dziedziny nauki lub dyscypliny naukowej, ze szczególnym uwzględnieniem wartości oryginalnych prac publikowanych lub wykonanych i zastosowanych opracowań istotnych dla postępu w nauce i technice; (2) dorobkiem naukowym zatrudnionych w jednostce pracowników naukowo-dydaktycznych w zakresie dyscypliny naukowej lub pracowników naukowo-badawczych specjalizujących się w dziedzinie nauki lub w zakresie dyscypliny naukowej, odpowiadającej uprawnieniu.
} 
wniosku, chyba że ten nie spełniałby wymagań (w zakresie minimum kadrowego). Nie można tu jednak nie dostrzec, że w ocenie drugiego z wymagań (poziomu działalności naukowej jednostki, niezależnej od tzw. minimum kadrowego) Centralna Komisja dysponowała znaczną dyskrecjonalnością. Założenia przyjęte pod rządami drugiej ustawy były odmienne. Poza wymaganiami określonymi w ustawie ta upoważniła właściwego ministra do ustalenia trybu składania wniosków ${ }^{41}$, zarazem wskazała elementy objęte wnioskiem. Od danej jednostki organizacyjnej wymagano: sprawozdania z działalności naukowo-badawczej lub twórczości artystycznej (z ostatnich trzech lat przed złożeniem wniosku), imiennego wykazania potencjału naukowego reprezentowanego przez samodzielnych pracowników nauki, z charakterystyką ich osiągnięć w zakresie kształcenia kadr i własnych osiągnięć naukowych oraz potencjału właściwej rady (wydziału, naukowej), a także charakterystyki bazy badawczej jednostki. Od 2011 r. również opinii Polskiej Komisji Akredytacyjnej dotyczącej jakości kształcenia w jednostce organizacyjnej, jeśli ta prowadzi kształcenie (art. 7 ust. 1$)^{42}$.

Ocenę złożonych przez jednostki organizacyjne wniosków oraz rozstrzygnięcie o nadaniu im uprawnienia do nadawania stopnia naukowego doktora habilitowanego zarówno ustawa pierwsza, jak i druga powierzyły Centralnej Komisji. Zadanie tej Komisji w sposób naturalny było podporządkowane ocenie wymagań stawianych w tym zakresie przed jednostkami organizacyjnymi. Te zaś pod rządami obu ustaw były różnie zakreślone, poza wskazaniem minimalnej liczby osób zatrudnionych, w tym reprezentujących dziedzinę nauki lub dyscyplinę naukowa, w zakresie której jednostka organizacyjna mogła otrzymać uprawnienie. Ustawa pierwsza (w ślad za ustawą z 1965 r. w brzmieniu nadanym w $1985 \mathrm{r.}^{43}$ ) prawo do przeprowadzania przewodów habilitacyjnych

${ }^{41}$ Zob. Rozporządzenie Ministra Edukacji Narodowej i Sportu z dnia 27 I 2004 r. w sprawie trybu zgłaszania wniosków o przyznanie uprawnienia do nadawania stopni doktora i doktora habilitowanego (Dz.U. Nr 21, poz. 194).

${ }^{42}$ Jednostki organizacyjne zainteresowane nabyciem uprawnienia do nadawania stopnia doktora habilitowanego mogły składać wnioski w formie papierowej, od $2017 \mathrm{r}$. w dwóch egzemplarzach, bądź w formie dokumentu elektronicznego opatrzonego kwalifikowanym podpisem elektronicznym, za pomocą środków komunikacji elektronicznej - zob. Rozporządzenie Ministra Nauki i Szkolnictwa Wyższego z dnia 4 I 2017 r. zmieniające rozporządzenie w sprawie trybu zgłaszania wniosków o przyznanie uprawnienia do nadawania stopni doktora i doktora habilitowanego (Dz.U. poz. 75).

${ }^{43}$ Ustawa z dnia 25 VII 1985 r. o zmianie ustawy o stopniach i tytułach naukowych (Dz.U. Nr 36, poz. 168), a także wydane na jej podstawie Zarządzenie Ministra Nauki i Szkolnictwa Wyższego z dnia 11 III 1986 r. w sprawie szczegółowych warunków i trybu 
i nadawania stopnia naukowego doktora habilitowanego zarezerwowała dla jednostek, które zatrudniały w pełnym wymiarze czasu pracy co najmniej dwanaście osób posiadających tytuł naukowy lub stopień naukowy doktora habilitowanego, z tym że pracowników z tytułem naukowym reprezentujących dziedzinę nauki, w zakresie której jednostka mogła otrzymać uprawnienie, nie mogło być mniej niż sześciu ${ }^{44}$. Ustawa druga, choć nieco inaczej, precyzyjniej aniżeli ustawa pierwsza określiła wymagania odnoszone do minimalnej liczby osób, wzmocniła je o warunek nowy - od nich wymagała zatrudnienia w jednej jednostce organizacyjnej nie krócej niż przez rok. Od 2005 r. o kolejne nowe rozwiązanie - przyznające Centralnej Komisji w uzasadnionych przypadkach prawo uznania, że osoby reprezentujące pokrewne dziedziny nauki i sztuki, w tym pokrewne dyscypliny naukowe i artystyczne, spełniają warunki co do osób tworzących tzw. minimum kadrowe oraz reprezentujących dziedzinę nauki i dyscypliny naukowe (dziedzinę sztuki, dyscyplinę artystyczną) ${ }^{45}$. Częściowo inne rozwiązania przyniósł rok 2011. Ustawową nowelizacją z tego roku, po pierwsze, grupą zatrudnionych w pełnym wymiarze czasu pracy $w$ danej jednostce organizacyjnej co najmniej dwunastu osób posiadających tytuł naukowy lub stopień naukowy doktora habilitowanego mogły być objęte także osoby, które na podstawie decyzji rektora nabyły uprawnienie równoważne $\mathrm{z}$ uprawnieniem wynikającym z posiadania stopnia doktora habilitowanego $^{46}$ - dla których dana jednostka organizacyjna jest podstawowym miejscem pracy, przy zachowaniu ich zatrudnienia $\mathrm{w}$ danej jednostce w okresie nie krótszym niż rok, po drugie, z sześciu do trzech obniżyła

przeprowadzania przewodów doktorskich i habilitacyjnych oraz zakresu egzaminów doktorskich i kolokwiów habilitacyjnych (M.P. Nr 11, poz. 74).

${ }^{44}$ Obniżone w tym zakresie wymagania przyjęto wobec szkół artystycznych. Od nich wymagano zatrudnienia w pełnym wymiarze czasu pracy co najmniej siedmiu osób posiadających tytuł naukowy lub stopień doktora habilitowanego, w tym co najmniej pięciu osób z tytułem naukowym (art. 3 ust. 4 ustawy z 1990 r.), przy jednoczesnym założeniu, że uprawnieniem mogły być objęte tylko dziedziny w zakresie sztuki i dyscypliny artystyczne reprezentowane przez co najmniej trzy takie osoby.

${ }^{45}$ Artykuł 251 pkt 1 Ustawy z dnia 27 VII 2005 r. o szkolnictwie wyższym.

${ }^{46}$ Zgodnie z art. 21a Ustawy z dnia 18 III 2011 r. chodzi tu o osoby, które uzyskały stopień doktora w Rzeczypospolitej Polskiej lub za granicą i podczas pobytu w innym państwie przez co najmniej pięć lat kierowały samodzielnie zespołami badawczymi oraz posiadają znaczący dorobek i osiągnięcia naukowe i są zatrudnione w szkole wyższej na stanowisku profesora nadzwyczajnego lub profesora wizytującego. $W$ tej sprawie zob. też art. 3 Ustawy z dnia 25 IX 2015 r. o zmianie niektórych ustaw w związku ze wspieraniem innowacyjności (Dz.U. poz. 1767). 
liczbę pracowników z tytułem naukowym reprezentujących dziedzinę nauki, w zakresie której jednostka mogła otrzymać uprawnienie. Tym samym obniżono wymagania w tym zakresie, wbrew zapewnieniom przyjętym w rządowym uzasadnieniu do projektu ustawy z 2011 r. o potrzebie podwyższenia wymogów służących wyższej jakości naukowej promowanych habilitacji ${ }^{47}$. I ten stan prawny zachowano do czasu uchylenia ustawy z $2003 \mathrm{r}$.

Pozytywna ocena wniosku dla Centralnej Komisji pod rządami obu ustaw stanowiła podstawę rozstrzygnięcia o nadaniu wnioskującej jednostce organizacyjnej uprawnienia do nadawania stopnia doktora habilitowanego - w odniesieniu do jednostek organizacyjnych szkół wyższych po uprzednim zasięgnięciu opinii Rady Głównej Szkolnictwa Wyższego (Rady Głównej Nauki i Szkolnictwa Wyższego).

Nadanie jednostce organizacyjnej uprawnienia do nadawania stopnia naukowego doktora habilitowanego pod rządami obu ustaw nie zwalniało jej z obowiązku niezwłocznego zawiadomienia Centralnej Komisji o zmianach w stanie zatrudnienia wpływających na uprawnienie do nadawania tego stopnia naukowego. Gdy te miały miejsce, zawieszenie uprawnienia następowało z mocy prawa od dnia, w którym liczba pracowników zatrudnionych w danej jednostce zmniejszyła się poniżej wymagań - na jak długo, tego ustawa pierwsza nie określiła. Błędu tego nie powtórzono ustawą drugą. Na jej mocy dla przywrócenia przez jednostkę organizacyjną ustawowych wymagań w tym zakresie Centralna Komisja mogła: (1) zawiesić uprawnienia na okres nie dłuższy niż dwa lata ${ }^{48}$, a w razie ich niespełnienia (2) cofnąć uprawnienie ${ }^{49}$.

Nadanie jednostce organizacyjnej uprawnienia do nadawania stopnia naukowego doktora habilitowanego nie wyłączało również prawa Centralnej Komisji do przeprowadzania w niej okresowych ocen poziomu działalności naukowej lub artystycznej, a także zasadności

${ }^{47} \mathrm{~W}$ uzasadnieniu rządowego projektu ustawy nowelizującej ustawę z 2003 r., mimo projektowanej zmiany, pominięto milczeniem sprawę obniżenia wymagań postawionych przed jednostkami organizacyjnymi ubiegającymi się o nabycie uprawnienia do nadawania stopnia doktora habilitowanego, s. 6.

${ }^{48} \mathrm{~W}$ tej sytuacji przewody habilitacyjne wszczęte przed dniem zawieszenia uprawnienia mogły być przez tę jednostkę organizacyjną kontynuowane na warunkach określonych przez Centralną Komisję bądź przez jednostkę organizacyjną przez nią wskazaną (art. 8 ust. 4 ustawy z 2003 r.), od 2011 r. przez komisję powołaną przez Centralną Komisję dla wskazanej przez nią jednostki organizacyjnej uprawnionej do podjęcia uchwały o nadaniu lub odmowie nadania stopnia doktora habilitowanego (art. 8 ust. 5 w brzmieniu nadanym ustawą nowelizującą $\mathrm{z}$ tego roku).

${ }^{49}$ Artykuł 6 ust. 2 ustawy z 1990 r. oraz art. 8 ust. 2 i 3 ustawy z 2003 r. 
uchwał w sprawie nadawania tego stopnia naukowego. Centralna Komisja w wyniku oceny danej jednostki mogła wydać rozstrzygnięcie pozytywnie lub negatywnie. W sytuacji pierwszej - jeżeli ocena była szczególnie wysoka, mogła nadto postanowić, że uchwały rady danej jednostki o nadaniu stopnia naukowego doktora habilitowanego nie wymagają zatwierdzenia i stają się prawomocne z chwilą ich podjęcia $^{50}$ (art. 7 ust. 5 ustawy z 1990 r., art. 9 ust. 5 ustawy z 2003 r.), co było wysoce nobilitujące daną jednostkę. Od tego rozwiązania odstąpiono w 2005 r. ${ }^{51} \mathrm{~W}$ sytuacji drugiej natomiast Centralna Komisja mogła postanowić o: ograniczeniu bądź zawieszeniu udzielonego uprawnienia; albo o pozbawieniu jednostki organizacyjnej uprawnienia do nadawania stopnia naukowego doktora habilitowanego. Odpowiednio do oceny Centralna Komisja (w myśl ustawy pierwszej i drugiej) mogła: w pierwszym przypadku - ograniczyć uprawnienie jednostki organizacyjnej przez zobowiązanie jej do przedstawienia do zatwierdzenia każdej uchwały o nadaniu stopnia naukowego, w przypadku drugim - zawiesić uprawnienie na czas określony, nie dłuższy niż trzy lata, w przypadku trzecim - pozbawić tego uprawnienia (zgodnie z ustawą z 1990 r.), uprawnienie to cofnąć (zgodnie z ustawą z 2003 r.) ${ }^{52}$.

\subsection{Wykazy uprawnionych jednostek organizacyjnych do nadawania stopnia naukowego doktora habilitowanego}

Wzorem rozwiązań wcześniejszych obie ustawy (z 1990 i 2003 r.) zachowały obowiązek ogłaszania w Dzienniku Urzędowym "Monitor Polski" wykazów jednostek organizacyjnych uprawnionych do nadawania stopni naukowych wraz z określeniem nimi nazw nadawanych stopni naukowych. W odróżnieniu natomiast od rozwiązań wcześniejszych pozostawiających sporządzanie takich wykazów ministrowi właściwemu do spraw szkolnictwa wyższego ${ }^{53}$ art. 5 ust. 1 ustawy pierwszej kompetencję w tym zakresie powierzył Przewodniczącemu Centralnej Komisji, art. 7 ust. 2 ustawy drugiej - Centralnej Komisji.

${ }^{50}$ Postanowienie to mogło być, pod rządami obu ustaw, uchylone w razie zmiany tej oceny.

${ }^{51}$ Zob. art. 251 pkt 2 lit. a Ustawy z dnia 27 VII 2005 r. Prawo o szkolnictwie wyższym.

${ }^{52} \mathrm{~W}$ każdej z tych sytuacji podjęte uchwały wymagały od Centralnej Komisji ich ogłoszenia w Dzienniku Urzędowym „Monitor Polski”.

${ }^{53}$ Kompetencję w tym zakresie przed sporządzeniem nowych wykazów pod rządami ustawy z 1990 r. o tytule i stopniach naukowych posiadał Minister Edukacji Narodowej. 
Wraz z wejściem w życie ustawy z roku 1990 należało sądzić, że z upływem kadencji Centralnej Komisji z dniem 31 grudnia 1990 r. i wraz z wyborem nowego jej składu, zgodnie z art. 43 ust. 3 tejże ustawy, nie później niż do dnia 1 stycznia 1991 r. Komisja ta ogłosi wykaz jednostek organizacyjnych uprawnionych do nadawania stopni naukowych w okresie nie dłuższym niż do dnia 31 marca $1991 \mathrm{r}$. (tj. w dacie przyjętej art. 45 ustawy dla zachowania w mocy przepisów dotychczasowych aktów wykonawczych). Tak się nie stało. Problem nie $w$ tym, że do tej daty nadal obowiązywało - zgodnie z prawem Zarządzenie Ministra Edukacji Narodowej z dnia 28 czerwca 1988 r. w sprawie wykazu jednostek organizacyjnych uprawnionych do nadawania stopni naukowych ${ }^{54}$ z późniejszymi zmianami z 1989 i 1990 r. $^{55}$ Problem w tym, że wraz z upływem tego terminu Przewodniczący Centralnej Komisji nie wypełnił wynikającego z art. 5 ust. 1 ustawowego obowiązku ogłoszenia nowego wykazu jednostek organizacyjnych uprawnionych do nadawania stopni naukowych wraz z określeniem ich nazw. Przy jednoznacznie określonym terminie zachowania ważności przepisów dotychczasowych aktów wykonawczych, a z drugiej strony wraz z uchyleniem ich podstawy prawnej mocą art. 46 - dalsze stosowanie zarządzenia z 1988 r. było prawnie niedopuszczalne. Do czasu wydania kolejnego aktu wykonawczego na podstawie ustawy z 1990 r. powstała zatem luka prawna.

Z mocy tej ustawy pierwsze Obwieszczenie Przewodniczący Centralnej Komisji do Spraw Tytułu Naukowego i Stopni Naukowych ogłosił dopiero w 1996 r. ${ }^{56}$ Dwa kolejne w 1998 i 2002 r. Od początku wykazy

${ }^{54}$ M.P. Nr 24, poz. 215 - wydane na podstawie art. 4 ust. 3 Ustawy z dnia 31 III 1965 r. o stopniach i tytułach naukowych, w brzmieniu nadanym Ustawą z dnia 25 VII 1985 r. o zmianie ustawy o stopniach naukowych i tytułach naukowych (Dz.U. Nr 36, poz. 168 ze zm.).

${ }_{55}$ Zob. Zarządzenia Ministra Edukacji Narodowej o jednobrzmiącym tytule - zmieniające zarządzenie w spawie wykazu jednostek organizacyjnych uprawnionych do nadawania stopni naukowych z dnia 5 IV 1989 r. (M.P. Nr 12, poz. 97), z dnia 21 VIII 1989 r. (M.P. Nr 32, poz. 246), z dnia 5 IV 1990 r. (M.P. Nr 12, poz. 97) oraz z dnia 1 III 1990 r. (M.P. Nr 11, poz. 85) i z dnia 24 IX 1990 r. (M.P. Nr 35, poz. 284).

${ }^{56}$ Obwieszczenie Przewodniczącego Centralnej Komisji do Spraw Tytułu Naukowego i Stopni Naukowych z dnia 26 I 1996 r. w sprawie wykazu jednostek organizacyjnych uprawnionych do nadawania stopni naukowych, wraz z określeniem nazw nadawanych stopni naukowych (M.P. Nr 17, poz. 219). Znacznie wcześniej - na podstawie art. 37 ust. 2 i 4 w zw. z art. 5 ust. 1 ustawy z 1990 r. o tytule naukowym i stopniach naukowych ogłoszono Obwieszczenie Przewodniczącego Rady Wyższej Szkolnictwa Artystycznego z dnia 30 IX 1991 r. w sprawie wykazu jednostek organizacyjnych uprawnionych do 
jednostek organizacyjnych podporządkowano klarownemu układowi wewnętrznemu z ich podziałem na: (1) szkoły wyższe - uniwersytety; wyższe szkoły techniczne; akademie ekonomiczne; wyższe szkoły pedagogiczne; wyższe szkoły rolnicze; akademie nauk wojskowych; wyższe szkoły teologiczne; akademie medyczne; akademie wychowania fizycznego; od 2002 r. rozszerzonym o wyższe szkoły artystyczne oraz o międzyuczelniane jednostki organizacyjne; (2) placówki naukowe PAN oraz (3) instytuty naukowo-badawcze.

Od rozwiązań sprzed wejścia w życie ustawy z dnia 12 września 1990 r. wykazy sporządzone po tej dacie bezwzględnie się różnią. Różnice zawierają się zarówno w sferze organów właściwych do ich ogłaszania, jak i formy prawnej podejmowanych w tym zakresie czynności. Różnice są wyraźnie widoczne także w zbytnim uproszczeniu treści wykazów przez odstąpienie od ich sporządzania (i ogłaszania) z rozdzieleniem na wykazy jednostek organizacyjnych uprawnionych do nadawania stopnia naukowego doktora oraz wyłącznie stopnia doktora habilitowanego. To, co wykazy te różni od tych sporządzanych przed 1990 r., to również odejście od objęcia nimi samodzielnych placówek typu naukowo-dydaktycznego, co nie oznaczało odstąpienia od ich dalszego funkcjonowania ${ }^{57}$.

Pierwszym z wykazów, ogłoszonym w 1996 r. ${ }^{58}$, objęto łącznie: siedemdziesiąt dwie szkoły wyższe ${ }^{59}$, pięćdziesiąt cztery placówki naukowe PAN oraz sześćdziesiąt jednostek naukowo-badawczych. Porównując te dane odpowiednio z liczbą podmiotów objętych ostatnim z wykazów opublikowanym przed dniem wejścia w życie ustawy

przeprowadzania przewodów kwalifikacyjnych w zakresie dziedzin sztuki i dyscyplin artystycznych wraz z określeniem stopnia przyznanych uprawnień (M.P. Nr 35, poz. 258).

${ }^{57}$ Tę możliwość zapewniał art. 203 ustawy z dnia 12 IX 1990 r. (o szkolnictwie wyższym). Zgodnie z nim jednostki te (samodzielne placówki) utworzone przed dniem wejścia w życie ustawy z 1990 r. na podstawie dotychczasowych przepisów działają na podstawie nadanych im statutów. Właściwy minister mógł jednak placówki te przekształcić, łączyć bądź zmienić ich statuty.

${ }^{58}$ Obwieszczenie Przewodniczącego Centralnej Komisji do Spraw Tytułu Naukowego i Stopni Naukowych z dnia 26 I 1996 r. w sprawie wykazu jednostek organizacyjnych uprawnionych do nadawania stopni naukowych, wraz z określeniem nazw nadawanych stopni naukowych (M.P. Nr 16, poz. 17).

${ }^{59}$ Wykazem szkół wyższych objęto, zgodnie z wówczas przyjętym podziałem, następujące szkoły wyższe w liczbie podanej w nawiasach: uniwersytety (12), akademie ekonomiczne (5), wyższe szkoły pedagogiczne (5), wyższe szkoły rolnicze (9), akademie nauk wojskowych (1), wyższe szkoły teologiczne (2), akademie medyczne (11), akademie wychowania fizycznego (6). 
z 1990 r. ${ }^{60}$, są to zmiany dość znaczące. Wykaz z 1996 r. w połowie następnego roku ${ }^{61}$ rozszerzono o Wyższą Szkołę Pedagogiczną w Olsztynie i dwie placówki naukowe PAN ${ }^{62}$, zwiększając ich liczbę do pięćdziesięciu sześciu, oraz obniżono do pięćdziesięciu dziewięciu liczbę jednostek naukowo-badawczych ${ }^{63}$. Z końcem września 1998 r. kolejnym obwieszczeniem ${ }^{64}$ Przewodniczący Centralnej Komisji wprawdzie ogłosił nowy wykaz jednostek organizacyjnych uprawnionych do nadawania stopni naukowych, w zakresie ich liczby nie były to jednak istotne zmiany. Grupę szkół wyższych rozszerzono do liczby siedemdziesięciu pięciu - przez utworzenie Uniwersytetu Białostockiego (w miejsce dawnej filii Uniwersytetu Warszawskiego); w grupie wyższych szkół technicznych - Akademii Górniczo-Hutniczej im. Stanisława Staszica w Krakowie. Zwiększono także do pięćdziesięciu siedmiu liczbę placówek naukowych PAN przez utworzenie kolejnej placówki - Centrum Badań Kosmicznych w Warszawie oraz zachowano w niezmienionej wysokości liczbę pięćdziesięciu dziewięciu jednostek badawczo-rozwojowych. W pierwszym kwartale 2000 r. ${ }^{65}$ zmieniającym obwieszczeniem Przewodniczącego Centralnej Komisji listę szkół wyższych rozszerzono: w grupie uniwersytetów o dwie kolejne uczelnie (Uniwersytet Kardynała Stefana Wyszyńskiego oraz Uniwersytet Warmińsko-Mazurski w Olsztynie), co w efekcie zwiększyło z trzynastu do piętnastu liczbę uniwersytetów objętych wykazem; w grupie wyższych szkół technicznych - o Wyższą Szkołę Morską

${ }^{60}$ Przed dniem wejścia w życie ustawy z 1990 r. objęto nimi łącznie: pięćdziesiąt sześć szkół wyższych oraz sześćdziesiąt sześć jednostek naukowych, z czego trzydzieści cztery stanowiły placówki naukowe PAN i trzydzieści dwa instytuty naukowo-badawcze.

${ }^{61}$ Obwieszczenie Przewodniczącego Centralnej Komisji do Spraw Tytułu Naukowego i Stopni Naukowych z dnia 25 VII 1997 r. w sprawie zmian w wykazie jednostek organizacyjnych uprawnionych do nadawania stopni naukowych, wraz z określeniem nazw nadawanych stopni naukowych (M.P. Nr 52, poz. 499).

${ }^{62}$ W 1997 r. wykazem objęto nadto: Instytut Informatyki Teoretycznej i Stosowanej w Gliwicach oraz Instytut Ochrony Przyrody w Krakowie.

${ }^{63} \mathrm{Z}$ wykazu skreślono dwa instytuty (Instytut Ziemniaka, Wojskowy Instytut Historyczny) oraz dodano do niego Centralny Instytut Ochrony Pracy.

${ }^{64}$ Obwieszczenie Przewodniczącego Centralnej Komisji do Spraw Tytułu Naukowego i Stopni Naukowych z dnia 23 IX 1998 r. w sprawie wykazu jednostek organizacyjnych uprawnionych do nadawania stopni naukowych, wraz z określeniem nazw nadawanych stopni naukowych (M.P. Nr 38, poz. 524).

${ }^{65} \mathrm{Na}$ mocy Obwieszczenia Przewodniczącego Centralnej Komisji do Spraw Tytułu Naukowego i Stopni Naukowych z dnia 24 III 2000 r. w sprawie zmian w wykazie jednostek organizacyjnych uprawnionych do nadawania stopni naukowych, wraz z określeniem nazw nadawanych stopni naukowych (M.P. Nr 11, poz. 240). 
w Gdyni; w grupie akademii ekonomicznych o Wyższą Szkołę Przedsiębiorczości i Zarządzania w Warszawie, w grupie wyższych szkół pedagogicznych - o Wyższą Szkołę Pedagogiczną w Słupsku; w grupie wyższych szkół teologicznych - ponad jedną już działającą o cztery kolejne (Papieską Akademię Teologiczną w Krakowie, Wyższą Szkołę Filozoficzno-Pedagogiczną „Ignatianum” w Krakowie, Papieski Wydział Teologiczny w Warszawie, Papieski Wydział Teologiczny we Wrocławiu), pozostawiając poza wykazem Akademię Teologii Katolickiej, ponadto po raz pierwszy wykazem objęto $\mathrm{w}$ grupie międzyuczelnianych jednostek organizacyjnych - Międzyuczelniany Wydział Biotechnologii Uniwersytetu Gdańskiego i Akademii Medycznej w Gdańsku. Zmianom poddano także listę instytutów naukowo-badawczych przez dodanie dwóch nowych jednostek: Instytutu "Centrum Zdrowia Matki Polki” w Łodzi i Przemysłowego Instytutu Telekomunikacji w Warszawie, co w efekcie zwiększyło ogólną ich liczbę do sześćdziesięciu jeden instytutów.

W tym zakresie ostatnie, wydane na podstawie ustawy z 1990 r., obwieszczenie Przewodniczącego Centralnej Komisji z roku 2002 r. ${ }^{66}$ przyniosło nieco szersze zmiany, szczególnie w odniesieniu do szkół wyższych. Po pierwsze, wyraźniej zarysowała się tendencja do rozszerzania wykazu o nowo uprawnione państwowe szkoły wyższe, a zarazem do pominięcia nim niektórych ze szkół objętych wykazami wcześniejszymi, po drugie, po raz pierwszy wykazem objęto także pięć wyższych szkół niepaństwowych ${ }^{67}$. W grupie pierwszej wykazem ponadto objęto: Uniwersytet Medyczny w Lodzi, Uniwersytet Rzeszowski, Uniwersytet Zielonogórski (zwiększając tym samym ich liczbę do osiemnastu), w grupie wyższych szkół technicznych wykaz uzupełniono o: Akademię Techniczno-Humanistyczną w Bielsku-Białej, zarazem pomijając w nim Politechnikę Zielonogórską; w grupie szkół artystycznych (co stanowiło novum) wykazem objęto jedną szkołę - Akademię Muzyczną im. Fryderyka Chopina w Warszawie. Obniżono natomiast

${ }^{66}$ Obwieszczenie Przewodniczącego Centralnej Komisji do Spraw Tytułu Naukowego i Stopni Naukowych z dnia 18 XII 2002 r. w sprawie wykazu jednostek organizacyjnych uprawnionych do nadawania stopni naukowych, wraz z określeniem nazw nadawanych stopni naukowych (M.P. 2003 Nr 2, poz. 19).

${ }^{67} \mathrm{~W}$ wykazie znalazły się następujące szkoły wyższe niepaństwowe: Polsko-Japońska Szkoła Technik Komputerowych w Warszawie, Szkoła Wyższa Psychologii Społecznej w Warszawie, Wyższa Szkoła Humanistyczna im. Aleksandra Gieysztora w Pułtusku, Wyższa Szkoła Przedsiębiorczości i Zarządzania im. Leona Koźmińskiego w Warszawie, Wyższa Szkoła Ubezpieczeń i Bankowości w Warszawie. 
liczbę szkół wyższych - pedagogicznych (do sześciu), nie obejmując Wyższej Szkoły Pedagogicznej w Olsztynie, Wyższej Szkoły Pedagogicznej w Rzeszowie oraz Wyższej Szkoły Pedagogicznej im. Tadeusza Kotarbińskiego w Zielonej Górze, a zarazem dodając Wyższą Szkołę Pedagogiczną w Częstochowie; wyższych szkół rolniczych - obniżając ich liczbę z dziewięciu do ośmiu, wykazem nie objęto Akademii Rolniczo-Technicznej im. Michała Oczapowskiego w Olsztynie; akademii medycznych - wykazem obniżono ich liczbę z jedenastu do dziewięciu, nie obejmując: Akademii Medycznej w Łodzi oraz Wojskowej Akademii Medycznej im. Gen. Dyw. Bolesława Szareckiego w Łodzi. Zarazem wykazem tym zachowano w grupie szkół teologicznych liczbę pięciu tych szkół oraz jedną międzyuczelnianą jednostkę organizacyjną. W efekcie tych zmian i przy uwzględnieniu w grupie szkół ekonomicznych w niezmienionej liczbie pięciu uczelni; akademii wojskowych - jednej szkoły (od 2000 r. Akademii Obrony Narodowej); pięciu szkół teologicznych oraz sześciu akademii wychowania fizycznego - liczbę szkół wyższych zwiększono do osiemdziesięciu dwóch, co przy dodaniu do niej pięciu niepaństwowych szkół wyższych ogólną ich liczbę w rezultacie podniosło do osiemdziesięciu siedmiu. W tym czasie wprawdzie tego potencjału naukowego nie zmieniono w odniesieniu do placówek naukowych PAN (nadal było ich pięćdziesiąt siedem), to jednak liczbę jednostek badawczo-rozwojowych zachowano w wysokości sześćdziesięciu jeden, przez usunięcie z wykazu Instytutu Rozwoju Studiów Strategicznych w Warszawie oraz objęcie nim Wojskowego Instytutu Medycznego w Warszawie.

Wejście w życie ustawy z 2003 r. inaczej niż pod rządami ustawy z 1990 r. rozstrzygnęło problem przekazania kompetencji do sporządzania kolejnych wykazów. Po pierwsze, ustawodawca uznał, że wraz z upływem kadencji Centralnej Komisji do Spraw Tytułu Naukowego i Stopni Naukowych z dniem wejścia w życie tej ustawy ta staje się Centralną Komisją do Spraw Stopni Naukowych i Tytułów oraz że do czasu wydania przez nią przepisów wykonawczych pozostają w mocy przepisy dotychczasowych aktów wykonawczych, o ile nie są z ustawą tą sprzeczne. Tu już bez wyznaczenia limitu czasowego ich ważności. Biorąc pod uwagę upływ kadencji poprzedniej Centralnej Komisji z dniem 31 grudnia 2006 r. oraz datę ogłoszenia przez nowo obraną Centralną Komisję pierwszego wykazu (11 kwietnia 2007 r.), przyjęta technika legislacyjna nie może budzić większych zastrzeżeń. Poza tym, że nowo 
obrana Centralna Komisja pierwszy wykaz ogłosiła obwieszczeniem ${ }^{68}$, a nie w drodze uchwały, którą przewidywał art. 3 ust. 1 ustawy. Podobnie Komisja ta postapiła z ogłoszeniem kolejnego wykazu w roku 2010. Stosownie do rozwiązań przyjętych przed 2003 r. oba akty zachowały wewnętrzny układ treści wykazu, ale i brak rozdzielenia w nich jednostek organizacyjnych uprawnionych do nadawania stopni naukowych stosownie do ich wyróżnienia.

Pierwsze obwieszczenie Centralnej Komisji nie miało charakteru rewolucyjnego. Zmiana ilościowa jednostek organizacyjnych uprawnionych do nadawania stopni naukowych przewidzianych tym obwieszczeniem pozostawała na niezmienionym poziomie. Zwiększono nim jedynie o siedemnaście liczbe uczelni artystycznych oraz o siedem niepublicznych (odtąd tak nazywanych) szkół wyższych ${ }^{69}$. W rezultacie wykazem tym objęto dziewięćdziesiąt osiem szkół wyższych, co łącznie z uczelniami niepublicznymi, których liczbę rozszerzono do dwunastu, dało ich sto dziesięć. Zachowano dotychczasową liczbę placówek naukowych PAN, tj. pięćdziesiąt siedem. Obniżono natomiast o dziewięć (z sześćdziesięciu jeden do pięćdziesięciu dwóch) liczbę instytutów naukowo-badawczych, poza wykazem pozostawiając: Centrum Naukowo-Techniczne Kolejnictwa w Warszawie, Instytut Fizyki Jądrowej im. Henryka Niewodniczańskiego w Krakowie, Instytut Leków w Warszawie, Instytut Medycyny Morskiej i Tropikalnej w Gdyni, Instytut Medycyny Wsi im. Witolda Chodźki w Lublinie, Instytut Metalurgii Żelaza im. Stanisława Staszica w Gliwicach, Instytut Technologii Drewna w Poznaniu, Morski Instytut Rybacki w Gdyni, Wojskowy Instytut Techniki Pancernej i Samochodowej w Sulejówku.

Kolejnym wykazem wdrożonym Obwieszczeniem Centralnej Komisji z dnia 31 maja $2010 \mathrm{r}^{70} \mathrm{~W}$ istocie zachowano liczebne stutus quo

${ }^{68}$ Obwieszczenie Centralnej Komisji do Spraw Stopni i Tytułów z dnia 11 IV 2007 r. w sprawie wykazu jednostek organizacyjnych uprawnionych do nadawania stopni doktora i doktora habilitowanego wraz z określeniem nazw nadawanych stopni (M.P. Nr 41, poz. 462).

${ }^{69}$ Obwieszczeniem Centralnej Komisji z dnia 11 IV 2007 r. objęto nadto następujące uczelnie niepubliczne: Collegium Civitas w Warszawie, Dolnośląską Szkołę Wyższą Edukacji Towarzystwa Wiedzy Powszechnej we Wrocławiu, Górnośląską Wyższą Szkołę Handlową im. Wojciecha Korfantego w Katowicach, Społeczną Wyższą Szkołę Przedsiębiorczości i Zarządzania w Łodzi, Wyższą Szkołę Handlu i Prawa im. Ryszarda Łazarskiego w Warszawie, Wyższą Szkołę Humanistyczno-Ekonomiczną w Łodzi oraz Wyższą Szkołę Zarządzania Marketingowego i Języków Obcych w Katowicach.

${ }^{70}$ Obwieszczenie Centralnej Komisji do Spraw Stopni i Tytułów z dnia $31 \mathrm{~V}$ 2010 r. w sprawie wykazu jednostek organizacyjnych uprawnionych do nadawania 
podmiotów uprawnionych do nadawania stopni naukowych przyjętych obwieszczeniem Centralnej Komisji z 2007 r., z wyjątkami: z wykazu wyłączono jedną z ośmiu szkół wyższych rolniczych (Akademię Przyrodniczą w Szczecinie), Uniwersytet Medyczny w Łodzi objęto grupą akademii medycznych (a nie jak dotąd uniwersytetów) oraz rozszerzono liczbę niepublicznych szkół wyższych z dwunastu do piętnastu ${ }^{71}$. W ten sposób uprawnienie do nadawania stopni naukowych uzyskało: dziewięćdziesiąt siedem szkół wyższych, co po rozszerzeniu (z dwunastu do piętnastu) o niepubliczne szkoły wyższe łącznie pozostawiło je na poziomie stu dwunastu uczelni. Liczbę placówek naukowych PAN rozszerzono o cztery kolejne placówki (Instytut Biologii Medycznej w Łodzi, Instytut Fizjologii Roślin, Instytut Wysokich Ciśnień, Zakład Badań Środowiska Rolniczego i Leśnego w Poznaniu) do sześćdziesięciu jeden, natomiast wyłączając z wykazu jeden z instytutów naukowo-badawczych (Instytut Budownictwa, Mechanizacji i Elektryfikacji Rolnictwa w Warszawie), ich liczbę pozostawiono na poziomie pięćdziesięciu jeden.

Objęcie powyższymi wykazami trzech grup jednostek: szkół wyższych, placówek naukowych PAN oraz jednostek naukowo-badawczych w żadnym razie nie oznaczało prawa każdej z nich do nadawania stopnia naukowego doktora habilitowanego. Liczba uprawnień na przestrzeni lat objętych badaniem zmieniała się. To natomiast, co miało wartość stała, to założenie, że prawo do nadawania stopnia doktora habilitowanego było możliwe jedynie w przewidzianych wykazami dziedzinach nauki i dyscyplinach naukowych.

W badanym okresie liczba uprawnień do nadawania stopnia naukowego doktora habilitowanego, zgodnie z obwieszczeniami Przewodniczącego Centralnej Komisji opublikowanymi w latach 1996-2002 (z uwzględnieniem przyjętych w nich zmian) i Centralnej Komisji po 2002 r. oraz rozporządzeniem ministra z 2010 r. - wykazywała tendencję zmienną. W jej efekcie ilościowe ujęcie nadanych uprawnień w zakresie nadawania stopnia doktora habilitowanego podlegało zmianom czasowym, najczęściej uwarunkowanym: objęciem wykazem danej jednostki organizacyjnej (szkoły wyższej, placówki naukowej PAN lub instytutu naukowo-badawczego) bądź pominięciem jej innym wykazem;

stopni doktora i doktora habilitowanego wraz z określeniem nazw nadawanych stopni (M.P. Nr 46, poz. 636).

${ }^{71}$ Szkoły niepubliczne rozszerzono o: Akademię Finansów w Warszawie, Wyższą Szkołę Studiów Międzynarodowych w Łodzi oraz Krakowską Szkołę Wyższą. 
nadanie radzie właściwej jednostki organizacyjnej jednym wykazem uprawnienia w tym zakresie, innym zaś pozbawienia jej tego prawa. Nic więc dziwnego, że skala uprawnionych rad właściwych jednostek organizacyjnych ewoluowała ${ }^{72}$, i to zarówno gdy chodzi o szkoły wyższe ( $z$ uwzględnieniem ich podziału), jak i o placówki naukowe PAN oraz instytuty naukowo-badawcze. Na rok sporządzenia ostatniego z wykazów (2010) w drodze rozporządzenia ministra właściwego do spraw szkolnictwa wyższego łączna liczba udzielonych uprawnień w zakresie nadawania stopnia naukowego doktora habilitowanego wynosiła: czterysta jedenaście uprawnień w szkołach wyższych publicznych ${ }^{73}$

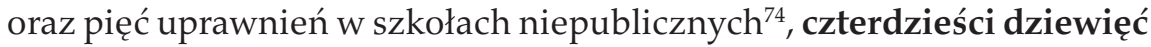

${ }^{72}$ Szczególnie wyraźnie jest to widoczne w odniesieniu do uniwersytetów. W poszczególnych latach w największym stopniu zmieniała się zarówno ich liczba, jak i liczba otrzymanych przez nie uprawnień (podana w nawiasie) do nadawania stopnia doktora habilitowanego w przyjętych dziedzinach nauki i dyscyplinach naukowych. Począwszy od 1996 r., dysponował nim każdy z uniwersytetów w następujących proporcjach: 1. Katolicki Uniwersytet Lubelski w 1996 (6), od 1998 (5), od 2002 (6), od 2007 (7), od 2010 (6); 2. Uniwersytet Gdański od 1996 (10); od 1998 (10); od 2002 (10); od 2007 (10); od 2010 (11); 3. Uniwersytet im. Adama Mickiewicza w Poznaniu od 1996 (13); 1998 (13); od 2002 (13); od 2007 (15); od 2010 (16); 4. Uniwersytet Jagielloński w Krakowie od 1996 (12); od 1998 (12); od 2002 (14); od 2007 (15); od 2010 (15); 5. Uniwersytet Marii Curie-Skłodowskiej w Lublinie od 1996 (10); od 1998 (10); od 2002 (11); od 2007 (11); od 2010 (12); 6. Uniwersytet Lódzki od 1996 (10); od 1998 (10); od 2002 (11); od 2007 (11); od 2010 (11); 7. Uniwersytet Opolski od 1996 (1); od 1998 (2); od 2002 (3); od 2007 (3); od 2010 (4); 8. Uniwersytet Szczeciński od 1996 (2); od 1998 (2); od 2002 (4); od 2007 (5); od 2010 (6); 9. Uniwersytet Śląski w Katowicach od 1996 (6); od 1998 (7); od 2002 (8); od 2007 (10); od 2010 (11); 10. Uniwersytet Mikołaja Kopernika w Toruniu od 1996 (10); od 1998 (10); od 2002 (11); od 2007 (14); od 2010 (15); 11. Uniwersytet Warszawski od 1996 (17); od 1998 (18); od 2002 (18); od 2007 (18); od 2010 (19); 12. Uniwersytet Wrocławski od 1996 (11); od 1998 (11); od 2002 (12); od 2007 (11); od 2010 (14); 13. Uniwersytet w Białymstoku od 1998 (1); od 2002 (2); od 2007 (2); od 2010 (4); 14. Uniwersytet Kardynała Stefana Wyszyńskiego w Warszawie od 2002 (4); od 2007 (4); od 2010 (4); 15. Uniwersytet Rzeszowski od 2002 (1); od 2007 (1); od 2010 (1); 16. Uniwersytet Warmińsko-Mazurski w Olsztynie od 2002 (7); 2007 (9); od 2010 (11); 17. Uniwersytet Zielonogórski od 2002 (3); od 2007 (3); od 2010 (3); 18. Uniwersytet Kazimierza Wielkiego w Bydgoszczy od 2007 (2); od 2010 (2).

${ }^{73} \mathrm{Z}$ czego najwięcej uprawnień ( $w$ liczbach podanych w nawiasach) przysługiwało uniwersytetom (142), uczelniom technicznym (111), znacznie mniej innym szkołom wyższym: uczelniom ekonomicznym (19), uczelniom pedagogicznym (5); uczelniom rolniczym (41); akademiom nauk wojskowych (2); uczelniom teologicznym (6); uczelniom medycznym (27); akademiom wychowania fizycznego (6); uczelniom artystycznym (51); jednostkom międzyuczelnianym (1).

${ }^{74}$ W 2007 r. spośród dwunastu objętych wykazem uczelni niepublicznych po jednym uprawnieniu do nadawania stopnia naukowego doktora habilitowanego otrzymały: Szkoła Wyższa Psychologii Społecznej w Warszawie oraz Wyższa Szkoła Przedsiębiorczości 


\section{w placówkach naukowych PAN i trzydzieści jeden w instytutach naukowo-badawczych. W latach 1996-2010 (przed ogłoszeniem ostat- niego z wykazów) liczba ta podlegała zmianom5 i począwszy od 1996 r.,}

i Zarządzania im. Leona Koźmińskiego w Warszawie. Od 2010 r. ponadto Collegium Civitas w Warszawie, Wyższa Szkoła Technik Komputerowych oraz Szkoła Wyższa Psychologii Społecznej w Warszawie - drugie uprawnienie w zakresie nadawania stopnia doktora habilitowanego.

${ }^{75}$ Począwszy od pierwszego wykazu (1996 r.) i jego zmiany (w 1997 r.) szkoły wyższe nabyły dwieście sześćdziesiat dziewięć uprawnień, w tym siedem w $1997 \mathrm{r}$., z czego najwięcej uzyskały uniwersytety (104) oraz wyższe szkoły techniczne (79); akademie ekonomiczne (14); wyższe szkoły pedagogiczne (2); wyższe szkoły rolnicze (31), akademia nauk wojskowych (1); wyższe szkoły teologiczne (4), akademie medyczne (23), akademie wychowania fizycznego (4). W $1998 \mathrm{r}$. uniwersytety dysponowały już stu dziesiecioma uprawnieniami, szkoły techniczne - osiemdziesięcioma dwoma, niezmienioną liczbę uprawnień zachowały akademie ekonomiczne oraz akademie wychowania fizycznego. W różnym stopniu natomiast zmieniała się liczba uprawnień pozostałych szkół wyższych: wyższe szkoły pedagogiczne (3), wyższe szkoły rolnicze (43), akademia nauk wojskowych (3), wyższe szkoły teologiczne (5), akademie medyczne (22) - łącznie dwieście osiemdziesiąt sześć uprawnień. W roku 2000 niektórym uczelniom uprawnienia rozszerzono, co najczęściej wiązało się z poszerzaną liczbą uczelni. I tak większą liczbę uprawnień przyznano: uniwersytetom (o 15); wyższym szkołom technicznym (o 3); wyższym szkołom pedagogicznym (o 2); wyższym szkołom rolniczym (o 1); wyższym szkołom teologicznym (o 5); wyższym szkołom wychowania fizycznego (o 2). W efekcie zmian wprowadzonych $w$ roku 2000 liczba udzielonych uprawnień łacznie wynosiła już trzysta czternaście. Rok 2002 wprawdzie nie przyniósł większych zmian (liczba kolejnych uprawnień przyznanych szkołom wyższym wrosła o dziesięć, łącznie zatem wynosiła trzysta dwadzieścia cztery), jednak różnice ilościowe uprawnień po 2000 r. dla niektórych szkół zaznaczały się wyraźnie. Odtąd uniwersytety dysponowały już stu czterdziestu jeden uprawnieniami, wzrosła również liczba uprawnień wyższych szkół technicznych do dziewięćdziesięciu jeden; spadek liczby wcześniej udzielonych uprawnień dotyczył: szkół rolniczych (40), akademii medycznych (19) oraz akademii nauk wojskowych (z 3 do 2). Pozostałe szkoły wyższe zachowały uprawnienia na niezmienionym poziomie. Uprawnień nie otrzymały wyższe szkoły artystyczne; międzyuczelniana jednostka organizacyjna oraz szkoły wyższe niepaństwowe - po raz pierwszy objęte wykazem. W roku 2007 łaczna liczba otrzymanych uprawnień, w tym dwa, które otrzymały po raz pierwszy szkoły wyższe niepubliczne, wynosiła trzysta czterdzieści dziewięć, z czego zwiększyła się liczba uprawnień: uniwersytetów do stu pięćdziesięciu jeden, akademii ekonomicznych do dziewiętnastu; wyższych szkół rolniczych do czterdziestu dwóch; uczelni medycznych do dwudziestu pięciu; uczelni artystycznych do czterdziestu siedmiu. Obniżyła się natomiast liczba uprawnień w grupie wyższych szkół technicznych do czterdziestu pięciu oraz wyższych szkół pedagogicznych do czterech.

W latach 1996-2010 różnie kształtowała się także liczba uprawnień, które otrzymały: (1) placówki naukowe PAN: poczynając od liczby czterdziestu pięciu w 1996 r., w następnych latach rozszerzonych lub obniżonych do: czterdziestu siedmiu (1997), czterdziestu ośmiu (1998), pięćdziesięciu (2000), czterdziestu dziewięciu (2002), pięćdziesięciu (2007) 
dość znacznie odbiegała od liczby uprawnień, które rady właściwych jednostek organizacyjnych otrzymały przed tym rokiem ${ }^{76}$.

W roku 2011 ustawa nowelizująca wprawdzie nadała nowe brzmienie art. 7 ust. 1 ustawy z 2003 r., jednak treści ust. 2 tego przepisu nie zmieniła ani nie uchyliła. Ten tryb postępowania legislacyjnego oczywiście nie budził żadnych wątpliwości. Bez wątpienia przesądzał jednak o zachowaniu mocy obowiązującej art. 7 ust. 2. Przepis ten nakładał na Centralną Komisję obowiązek ogłoszenia wykazów jednostek organizacyjnych uprawnionych do nadawania stopnia doktora habilitowanego i ich opublikowania w Dzienniku Urzędowym „Monitor Polski". Treść tego przepisu zachowały także kolejne zmiany ustawy z 2003 r. ${ }^{77}$ Ustawy te, w ślad za nowelizującą ustawą z 2011 r., zachowały także przyjętą nią zmianę art. $36^{78}$ Centralnej Komisji powierzająca m.in. zamieszczanie na swojej stronie internetowej informacji o jednostkach organizacyjnych uprawnionych do nadawania stopni wraz z wykazem tych stopni. W żadnym razie nie oznaczało to zwolnienia Centralnej Komisji z obowiązku publikowania na łamach wskazanego dziennika promulgacyjnego wykazów, o których stanowił art. 7 ust. 2 ustawy z 2003 r. Wobec ich nieopublikowania do 2018 r., a zarazem nieuchylenia do tego roku podstawy prawnej do ogłoszenia wykazów jednostek organizacyjnych uprawnionych do nadawania stopni naukowych obowiązywało nadal Obwieszczenie Centralnej Komisji z dnia 31 maja $2010 \mathrm{r}$.

oraz (2) instytuty naukowo-badawcze: trzydziestu czterech (1996), trzydziestu pięciu (1997), trzydziestu czterech (1998), trzydziestu sześciu (2002), trzydziestu dwóch (2007).

${ }^{76}$ Przed pierwszym z wykazów ogłoszonych przez Centralną Komisję w 1996 r. szkoły wyższe w roku 1987 dysponowały ogółem trzystu czterdziestoma pięcioma uprawnieniami do nadawania stopnia doktora habilitowanego, a w 1988 r. miały ich trzysta pięćdziesiąt jeden. Z kolei placówki naukowe PAN w roku 1987 miały trzydzieści pięć uprawnień, a w 1988 r. czterdzieści trzy. Natomiast instytuty naukowo-badawcze w 1987 r. otrzymały trzydzieści uprawnień, a w 1988 r. trzydzieści siedem. Szerzej zob. K. Wojtczak, Habilitacje w Polsce Ludowej. Część 2: Warunki i przebieg habilitacji w prawie o stopniach i tytułach naukowych, "Studia Prawa Publicznego" 2017, nr 2(18), s. 43 i n.

77 Zob. art. 2 pkt 5 ustawy nowelizującej z 2011 r., a także art. 7 ust. 2 w brzmieniu zachowanym kolejnymi zmianami Ustawy z dnia 14 III 2003 r. o stopniach naukowych i tytule naukowym oraz o stopniach i tytule w zakresie sztuki: $\mathrm{z}$ dnia 11 VII $2014 \mathrm{r}$. o zmianie ustawy Prawo o szkolnictwie wyższym oraz niektórych innych ustaw (tekst jedn. Dz.U. poz. 1852), z dnia 23 VI 2016 r. o zmianie ustawy Prawo o szkolnictwie wyższym oraz niektórych innych ustaw (Dz.U. poz. 1311).

${ }^{78}$ Przed nowelizacją ustawy z 2011 r. przepis ten brzmiał następująco: „Centralna Komisja przesyła jednostkom organizacyjnym roczne sprawozdania ze swojej działalności”. 


\section{Warunki i przebieg procedury habilitacyjnej}

W odróżnieniu od rozwiązań obowiązujących przed rokiem $1990 \mathrm{r}$. obie ustawy (z 1990 oraz z 2003 r.) normowały warunki i przebieg przewodów (od 2011 r. postępowań) habilitacyjnych z różnym stopniem szczegółowości. Znacznie węższym w roku 1990, co w praktyce mogło budzić pewne pytania, szerszym, a zarazem legislacyjnie staranniejszym w 2003 r. I tego oglądu rzeczy zbytnio nie zmieniały nowelizacje każdej z tych ustaw, co nie znaczy, że żadnych wątpliwości nie rodziły. I to zarówno wtedy, gdy określały zakres wymagań stawianych jednostkom organizacyjnym uprawnionym do przeprowadzania habilitacji; wskazania, kto mógł być dopuszczony do przewodu (postępowania) habilitacyjnego oraz jakim warunkom powinny odpowiadać rozprawy habilitacyjne (od 2011 r. osiągnięcia naukowe lub artystyczne), a także wtedy, gdy regulowały tryb postępowania w zakresie podejmowania uchwał kończących postępowanie nadaniem stopnia doktora habilitowanego.

Pod rządami obu ustaw uprawnienie do nadawania stopnia doktora habilitowanego mogło do 2011 r. obejmować tylko te dyscypliny naukowe, które $\mathrm{w}$ danej jednostce organizacyjnej były reprezentowane przez co najmniej pięciu pracowników z tytułem naukowym lub stopniem naukowym doktora habilitowanego (art. 3 ust. 5 ustawy pierwszej, art. 6 ust. 3 ustawy drugiej, od 2011 r. lub przez osoby, które nabyły uprawnienia równoważne $\mathrm{z}$ uprawnieniami doktora habilitowanego na podstawie art. 21a), a w zakresie sztuki i dyscyplin artystycznych (od 2003 r.) - przez co najmniej trzy takie osoby w myśl ustawy pierwszej, pięć - zgodnie z ustawą drugą. I tego stanu prawnego nie zmieniono po $2011 \mathrm{r}$.

Także wzorem rozwiązań wcześniejszych do przewodu habilitacyjnego mogła być dopuszczona osoba, która legitymując się stopniem naukowym doktora, uzyskała znaczny dorobek naukowy lub artystyczny i przedłożyła w pięciu egzemplarzach opublikowaną rozprawę habilitacyjną (art. 14 ustawy z 1990 r., art. 16 ustawy z 2003 r.). Tak jak przed 1990 r., wszczęcie przewodu habilitacyjnego na mocy ustawy pierwszej wymagało złożenia wniosku przez kandydata, w latach 2003-2011 przez kandydata lub za jego zgodą przez jednostkę organizacyjną go zatrudniającą ${ }^{79}$, po 2011 r. przez kandydata z możliwością wyboru jednostki

${ }^{79}$ Do wniosku składanego kierownikowi danej jednostki organizacyjnej (dziekanowi wydziału, kierownikowi placówki, instytutu) kandydat był obowiązany dołączyć: 
organizacyjnej uprawnionej do nadawania stopnia naukowego doktora habilitowanego ${ }^{80}$.

Innej ocenie podlegają natomiast warunki i tryb przeprowadzania przewodu habilitacyjnego. W okresie objętym analizą uwarunkowania prawne w tym zakresie podlegały zmianom. Wyznaczały je dwa kierunki: zliberalizowanie prawa pod rządami ustawy z $1990 \mathrm{r}$. i stopniowe jego zaostrzanie, począwszy od 2003 r., by po nowelizacji tej ustawy w roku 2011 w stopniu znaczącym uprościć warunki przebiegu postępowania habilitacyjnego przy zaostrzeniu wymagań stawianych przed kandydatami do stopnia naukowego doktora habilitowanego.

Nie bez uzasadnienia można zatem mówić o warunkach i trybie przeprowadzania przewodów habilitacyjnych ukształtowanych prawem obowiązującym przed rokiem 2011 oraz po tej dacie.

$\mathrm{w}$ oryginale lub w uwierzytelnionym odpisie dokument stwierdzający uzyskanie stopnia naukowego doktora; autoreferat (od 2004 r. informujący o zainteresowaniach i osiągnięciach w działalności naukowo-badawczej lub artystycznej); wykaz opublikowanych prac naukowych lub twórczych prac zawodowych bądź artystycznych, albo - od $2004 \mathrm{r}$. dokumentację dorobku artystycznego wraz z odpowiednim zapisem dzieł artystycznych i dokumentacją ich publikacji; rozprawę habilitacyjną w pięciu egzemplarzach; uzupełniony o przedstawienie informacji o przebiegu przewodu habilitacyjnego (od 2004 r. także przewodu kwalifikacyjnego) w sytuacji, gdy wnoszący wniosek wcześniej ubiegał się o nadanie stopnia naukowego doktora habilitowanego lub (od 2004 r.) kwalifikacji II stopnia ( $\$ 11$ rozporządzenia z dnia 8 X 1991 r., § 11 rozporządzenia z 2004 r.). Począwszy od 1990 r., odstąpiono od obowiązku przedłożenia przez kandydata jego dokładnego życiorysu ze szczególnym przedstawieniem przebiegu pracy zawodowej i naukowej.

${ }^{80}$ Począwszy od 2011 r., do składanego wniosku kandydat był obowiązany dołączyć: oryginał lub poświadczoną przez jednostkę organizacyjną przeprowadzającą postępowanie habilitacyjne kopię dokumentu stwierdzającego posiadanie stopnia doktora albo kwalifikacje I stopnia w zakresie sztuki i dyscypliny artystycznej (od 2014 r. na mocy Rozporządzenia Ministra Nauki i Szkolnictwa Wyższego z dnia 3 X 2014 r. w sprawie szczegółowego trybu i warunków przeprowadzania czynności w przewodzie doktorskim, w postępowaniu habilitacyjnym oraz w postępowaniu o nadanie tytułu profesora (Dz.U. poz. 1383) wystarczyło przedłożenie poświadczonej przez jednostkę organizacyjną wybraną do przeprowadzenia postępowania habilitacyjnego kopii dokumentu poświadczającego posiadanie stopnia doktora (i było to rozwiązanie słuszne); autoreferatu w obu wersjach językowych - polskiej i angielskiej oraz wykazu opublikowanych prac naukowych, zawodowych wraz z podaniem informacji o osiągnięciach dydaktycznych, w kształceniu młodej kadry naukowej i działalności popularyzującej naukę). Zob. też Rozporządzenia Ministra Nauki i Szkolnictwa Wyższego pod jednobrzmiącym tytułem w sprawie szczególnego trybu i warunków przeprowadzania czynności w przewodzie doktorskim, w postępowaniu habilitacyjnym oraz w postępowaniu o nadanie tytułu profesora: z dnia 10 XI 2015 r. (Dz.U. poz. 1842); z dnia 26 IX 2016 r. (Dz.U. poz. 1586) oraz z dnia 19 I 2018 r. (Dz.U. poz. 261). 


\subsection{Przebieg przewodu habilitacyjnego w latach 1990-2011}

Na mocy ustaw z 1990 i 2003 r. oraz wydanych na ich podstawie rozporządzeń z dnia 8 października $1991 \mathrm{r}^{81}$ i z dnia 15 stycznia $2004 \mathrm{r} .{ }^{82}$ przewód habilitacyjny obejmowat:

1. wszczęcie przewodu habilitacyjnego - w drodze uchwały ${ }^{83}$ podjętej przez właściwą radę (wydziału, naukową) danej jednostki organizacyjnej. Rada mogła też powołać zespół (przed 1990 r. obowiązkowo komisję) spośród swych członków z tytułem naukowym lub stopniem naukowym doktora habilitowanego ${ }^{84}$ (w liczbie przez obie ustawy nieokreślonej), dla przygotowania wniosku w przedmiocie wszczęcia przewodu, po zaznajomieniu się przez zespół z wymaganiami ustawowymi wniosku (co można było jedynie domniemywać) ${ }^{85}$.

${ }^{81}$ Rozporządzenie Prezesa Rady Ministrów z dnia 8 X 1991 r. w sprawie szczegółowego trybu przeprowadzania czynności w przewodach doktorskich i habilitacyjnych oraz w postępowaniu o nadanie tytułu profesora (Dz.U. Nr 92, poz. 410 ze zm.).

${ }^{82}$ Rozporządzenie Ministra Edukacji Narodowej i Sportu z dnia 15 I 2004 r. w sprawie szczegółowego trybu przeprowadzania czynności w przewodach doktorskim i habilitacyjnym oraz w postępowaniu o nadanie tytułu profesora (Dz.U. Nr 15, poz. 128 ze zm.)

${ }^{83}$ Właściwe rady uchwałę tę (oraz uchwały w sprawie wyznaczenia recenzentów; dopuszczenia do kolokwium habilitacyjnego; przyjęcia kolokwium habilitacyjnego [w latach 1990-2003 także przyjęcia wykładu habilitacyjnego] i nadania stopnia naukowego doktora habilitowanego) mogły podjąć w tajnym głosowaniu bezwzględną większością oddanych głosów, przy obecności co najmniej połowy ogólnej liczby osób uprawnionych do głosowania. Prawem głosu dysponowali członkowie rady właściwej jednostki organizacyjnej z tytułem naukowym profesora lub stopniem naukowym doktora habilitowanego, a ponadto osoby zaproszone do uzupełnienia składu rady przez osoby niebędące członkami tej rady, jeżeli jej uzupełnienie zarządziła Centralna Komisja na wniosek danej jednostki organizacyjnej lub z urzędu, a w przewodach o nadanie stopnia doktora habilitowanego w zakresie sztuki (od 2003 r.) - członkowie rady posiadający tytuł profesora lub stopień doktora habilitowanego sztuki. Uprawnienie to przysługiwało również recenzentom rozprawy habilitacyjnej (art. 18 ust. 1 i 2 w zw. z art. 8 ustawy z 1990 r.; art. 20 ust. 1 i 2 w zw. z art. 10 ustawy z 2003 r.).

${ }^{84}$ Zob. § 13 rozporządzenia z 1991 r., § 13 rozporządzenia z 2003 r.

${ }^{85}$ Rozwiązania obowiązujące przed wejściem w życie ustawy z 1990 r. przewidywały powołanie stosownej w tym zakresie komisji złożonej z co najmniej pięciu osób - członków danej rady z tytułem naukowym lub zajmujących stanowisko docenta i posiadających stopień naukowy doktora habilitowanego, przy założeniu, że większość członków komisji miała tytuł naukowy. Przewodniczącemu Komisji przysługiwały w zakresie przekazanych czynności uprawnienia dziekana (przewodniczącego rady naukowej). Członkowie komisji nie mogli łączyć tej funkcji z funkcją recenzenta (zob. ustawę z 1965 r. w brzmieniu nadanym Ustawą z dnia 25 VII 1985 r. o zmianie ustawy o stopniach naukowych i tytułach naukowych (Dz.U. Nr 26, poz. 168) oraz Zarządzenie Ministra Nauki i Szkolnictwa Wyższego z dnia 11 III 1986 r. w sprawie 


\section{2. ocenę dorobku naukowego kandydata oraz rozprawy habilita-} cyjnej. Mimo że ani ustawa z 1990 r., ani z 2003 r. nie wyjaśniały pojęcia dorobku naukowego kandydata, obie wyraźnie podkreśliły znaczenie obu komponentów oceny (dorobku naukowego i rozprawy habilitacyjnej) w recenzjach habilitacyjnych. Rozprawa habilitacyjna miała bowiem stanowić znaczny wkład autora w rozwój określonej dyscypliny naukowej (pod rządami ustawy z 1965 r. poważny wkład w rozwój określonej dziedziny nauki i dyscypliny naukowej) i być, przy zachowaniu tego warunku, dziełem opublikowanym w całości lub w zasadniczej części bądź w formule jednotematycznego cyklu publikacji; pracy zbiorowej z wyraźnym zaznaczeniem indywidualnego wkładu kandydata. Rozprawę habilitacyjną mogło też stanowić osiągnięcie projektowe, konstrukcyjne lub technologiczne (art. 15 ustawy z 1990 r., art. 17 ustawy z 2003 r.). Rozprawa habilitacyjna miała być opublikowana bez względu na to, czy było to dzieło czy publikacja ujęta w innej formie przekazu. Wyłączeniu publikacji podlegała jedynie rozprawa, której przedmiot był objęty tajemnicą państwową. Warunek ten był spełniony także w sytuacji upowszechnienia rozprawy w społeczności naukowej danej dziedziny nauki, po powiadomieniu wszystkich jednostek organizacyjnych działających w zakresie tej dziedziny - przewidziany wyłącznie ustawą pierwszą (art. 15 ust. 2 ustawy z 1990 r.). Nie można jednak w odniesieniu do tych przypadków wykluczyć braku wymagania (obie ustawy w tym zakresie milczą) przedłożenia rozprawy $\mathrm{w}$ formie maszynopisu - również w pięciu egzemplarzach.

W odróżnieniu od rozwiązań obowiązujących przed 1990 r. ani ustawa z tego roku, ani z roku 2003 nie wypowiadały się w zakresie języka rozprawy. Prawo przedłożenia opublikowanej rozprawy habilitacyjnej w języku polskim dziwić nie mogło. W tym jednak kontekście zastanawia, co legło u podstaw odstąpienia od możliwości przedłożenia rozprawy w obcym języku z załączonym do niej obszernym streszczeniem $\mathrm{w}$ języku polskim - co nie byłoby rozwiązaniem nowym w polskich uregulowaniach.

Rada (wydziału, naukowa) wraz z decyzją o wszczęciu przewodu habilitacyjnego powoływała (w drodze uchwały) co najmniej trzech recenzentów spośród osób posiadających tytuł lub stopień naukowy doktora habilitowanego w zakresie danej lub pokrewnej dziedziny nauki

szczegółowych warunków i trybu przeprowadzania przewodów doktorskich i habilitacyjnych oraz zakresu egzaminów doktorskich i kolokwiów habilitacyjnych (M.P. Nr 11, poz. 74). 
lub sztuki (art. 18 ust. 4 ustawy z 1990 r.), od 2003 r. w zakresie danej lub pokrewnej dyscypliny naukowej lub artystycznej (art. 20 ust. 6 ustawy z 2003 r. $)^{86}$. Rok $2005^{87}$ przyniósł podwyższenie liczby recenzentów do czterech, powoływanych po dwóch przez radę właściwej jednostki organizacyjnej oraz Centralną Komisję. Jednocześnie zastrzeżono, że nie więcej niż jeden z recenzentów mógł być zatrudniony w tej samej szkole wyższej (placówce naukowej), której pracownikiem była osoba ubiegająca się o nadanie stopnia doktora habilitowanego (1990, 2003) albo będąca członkiem rady jednostki organizacyjnej przeprowadzającej przewód (2003 r.). Począwszy od 2003 r., jednym z recenzentów mogła być także osoba będąca pracownikiem zagranicznej szkoły wyższej lub instytucji naukowej nieposiadająca polskiego stopnia naukowego doktora habilitowanego lub tytułu profesora (co było nowym rozwiązaniem), jeżeli właściwa rada uznała, że osoba ta jest wybitnym znawcą problematyki, której dotyczyła rozprawa habilitacyjna. Czy recenzentem mógł być również emerytowany profesor, obie ustawy milczały. W odróżnieniu od rozwiązań przyjętych przed $1990 \mathrm{r}$. ustawa pierwsza nie przesądzała o służbowym obowiązku sporządzenia recenzji, ustawa druga obowiązek ten już wyraźnie przywróciła ${ }^{88}$, w uzasadnionych przypadkach przewidując możliwość zwolnienia w tym zakresie (art. 30 ust. 1).

Recenzja, którą należało przedłożyć nie później niż w terminie trzech miesięcy po otrzymaniu rozprawy (w uzasadnionych przypadkach rada mogła przedłużyć termin przedstawienia recenzji $-\S 12 \mathrm{w}$ zw. z $\S 5$ ust. 3 rozporządzenia z 1991 r.), miała być szczegółowo uzasadnioną ocena, po pierwsze tego - czy rozprawa habilitacyjna odpowiada warunkom ustawowym, po drugie - czy dorobek naukowy lub artystyczny kandydata uzasadniał nadanie stopnia naukowego doktora habilitowanego. To zastrzeżenie, w przypadku powołania zespołu, miało istotne

${ }^{86}$ Użycie partykuły „lub” może zastanawiać, czy wyznaczenie recenzentów wyłącznie ze stopniem naukowym doktora habilitowanego czyni zadość przyjętym w obu ustawach rozwiązaniom. Biorąc pod uwagę tzw. minimum kadrowe wymagane dla otrzymania uprawnienia do nadawania stopnia naukowego doktora habilitowanego, raczej należałoby wykluczyć tę możliwość. Z drugiej strony, biorąc pod uwagę funkcję tzw. minimum kadrowego, nie jest to już tak oczywiste. Nie bez znaczenia ustawa w brzmieniu obowiązującym przed 1990 r. jednoznacznie przyjmowała, że spośród co najmniej trzech recenzentów co najmniej dwóch miało posiadać tytuł naukowy.

${ }_{87}$ Zob. art. 5a i 5b dodane art. 251 Ustawy z dnia 27 VII 2005 r. Prawo o szkolnictwie wyższym.

88 Pierwotnie obowiązek ten wprowadzono Rozporządzeniem Rady Ministrów z dnia 8 II 1966 r. w sprawie warunków i trybu przeprowadzania przewodów doktorskich i habilitacyjnych (Dz.U. Nr 8, poz. 53 ze zm.). 
znaczenie dla jego dalszych prac. To na nim spoczywał wówczas ciężar sprawdzenia, czy recenzje odpowiadały stawianym im przez ustawę wymaganiom; jeśli nie, zespół mógł zarządzić ich uzupełnienie. Ostatecznie o podjęciu uchwały o dopuszczeniu kandydata do dalszych etapów postępowania habilitacyjnego przesądzała w drodze uchwały właściwa rada. Jej uchwała negatywna (niedopuszczająca do kolokwium habilitacyjnego) miała ten skutek, że rozprawa habilitacyjna przedstawiona $\mathrm{w}$ tym przewodzie nie mogła stanowić podstawy do wszczęcia przewodu habilitacyjnego w innej jednostce organizacyjnej ( $\$ 15$ ust. 1 rozporządzenia z 1991 r., art. 18 ust. 3 ustawy z 2003 r.).

3. kolokwium habilitacyjne. Ani ustawy (z 1990 i 2003 r.), ani wydane na ich podstawie rozporządzenia (z 1991 i 2004 r.) nie regulowały materialno-prawnych aspektów przebiegu kolokwium habilitacyjnego. Można było jedynie domniemywać, że jego przedmiotem będzie co najmniej przedstawienie przez recenzentów ich opinii w sprawie dorobku naukowego i rozprawy habilitacyjnej kandydata oraz publiczna dyskusja i stanowisko (ewentualne odpowiedzi) kandydata. Uwagę prawodawca skoncentrował wyłącznie na stronie formalnoprawnej, stanowiąc, że: (1) kolokwium habilitacyjne przeprowadza się na posiedzeniu właściwej rady jednostki organizacyjnej z udziałem recenzentów, z obowiązkowym odczytaniem recenzji w razie nieobecności jednego z nich; (2) w obecności kandydata, a w sytuacji pracy habilitacyjnej jako rozprawy zbiorowej - każdego z autorów rozprawy ubiegających się o nadanie stopnia naukowego doktora habilitowanego w tej samej jednostce organizacyjnej. I było to rozwiązanie trafne, lecz nie nowe, powtórzone za rozwiązaniami przyjętymi w $1985 \mathrm{r}$.

Decyzję co do wyniku kolokwium podejmowała właściwa rada (wydziału, naukowa). Uchwała rady mogła być pozytywna lub negatywna. W sytuacji drugiej (negatywnej oceny kolokwium habilitacyjnego) rada wydziału (rada naukowa) mogła na wniosek kandydata zezwolić na jego powtórzenie $\mathrm{w}$ ustalonym przez radę terminie, nie krótszym niż sześć miesięcy i nie więcej niż jeden raz. Sytuacja pierwsza (uchwała o przyjęciu kolokwium habilitacyjnego) prowadziła do kolejnego etapu postępowania, $\mathrm{tj}$. do:

4. wykładu habilitacyjnego - do którego powrócono w $1985 \mathrm{r}^{89}$ Wykład habilitacyjny na jeden z trzech tematów zgłoszonych przez

${ }^{89}$ Wykładu habilitacyjnego nie przewidywały rozwiązania ustawy z dnia 31 III 1965 r. do czasu jej nowelizacji ustawą z dnia 25 VII 1985 r. 
kandydata radzie wydziału (radzie naukowej) do wyboru i przez nia wybrany (od 2004 r. bezpośrednio przed wykładem) miał być przez kandydata (kandydatów) wygłoszony na posiedzeniu rady danej jednostki organizacyjnej. Termin wygłoszenia wykładu ustalała rada. Było to dość elastyczne rozwiązanie, rada mogła bowiem wyznaczyć datę prowadzonego przewodu habilitacyjnego dla wygłoszenia przez kandydata wykładu, ale też mogła postąpić inaczej, co mogło się okazać szczególnie ważne $w$ razie wysłuchania wykładów na tym samym posiedzeniu rady przez wszystkich kandydatów równocześnie. W przeciwieństwie do rozwiązań sprzed 1990 r. ustawodawca nie przewidywał zwolnienia osób ubiegających się o nadanie stopnia naukowego doktora habilitowanego niebędących nauczycielami akademickimi od wygłoszenia wykładu habilitacyjnego. Po zakończeniu wykładu habilitacyjnego rada (wydziału, naukowa), biorąc pod uwagę oceny rozprawy habilitacyjnej i całego dorobku naukowego kandydata oraz ocenę przebiegu kolokwium habilitacyjnego i wykładu habilitacyjnego, podejmowała:

5. uchwałę $\mathbf{w}$ sprawie nadania stopnia naukowego doktora habilitowanego. Podjęcie tej uchwały obie ustawy zachowały dla rady (wydziału, naukowej) jednostki organizacyjnej kończącej przeprowadzony przez nią przewód habilitacyjny. Nie była to uchwała prawomocna. Nadanie jej prawomocności wymagało zatwierdzenia przez Centralną Komisję. Dochowania tego trybu postępowania nie wymagały jedynie uchwały tej rady, która w wyniku okresowej oceny dokonanej przez Centralną Komisję uzyskała szczególnie wysoką ocenę poziomu działalności naukowej lub artystycznej, a także zasadności uchwał w sprawie nadawania stopni naukowych. W każdym innym przypadku Centralna Komisja mogła, opierając się na uchwale rady (przedłożonej jej wraz z aktami przewodu habilitacyjnego ), zatwierdzić uchwałę o nadaniu stopnia doktora habilitowanego (w terminie do sześciu miesięcy) albo odmówić jej zatwierdzenia. W sytuacji pierwszej osobie, której nadano ten stopień naukowy, służyło prawo do dyplomu habilitacyjnego. W sytuacji drugiej z kolei właściwa rada jednostki organizacyjnej lub osoba ubiegająca się o nadanie stopnia naukowego doktora habilitowanego mogła w terminie trzech miesięcy od dnia doręczenia jej rozstrzygnięcia wystąpić do Centralnej Komisji z wnioskiem o ponowne rozpatrzenie sprawy. Ustawa pierwsza wyznaczyła Centralnej Komisji cztery miesiące na rozpatrzenie wniosku, ustawa druga termin ten wydłużyła do sześciu miesięcy. Diametralne zmiany w tym zakresie wprowadzono w 2005 r. ustawą - Prawo o szkolnictwie wyższym. Na mocy jej art. 251 przyjęto, 
że uchwała właściwej jednostki organizacyjnej o nadaniu stopnia naukowego doktora habilitowanego staje się prawomocna z chwilą jej podjęcia. I było to trafne rozwiązanie. Skracało w pewnym stopniu procedurę habilitacyjną bez uszczerbku dla jej znaczenia i wartości. Jedynie w przypadku niezatwierdzenia uchwały o nadaniu stopnia doktora habilitowanego podjętej przez radę jednostki organizacyjnej rada tej jednostki lub osoba ubiegająca się o nadanie tego stopnia naukowego mogła $w$ terminie 3 miesięcy od dnia doręczenia jej rozstrzygnięcia wystąpić do Centralnej Komisji z wnioskiem o ponowne rozpatrzenie sprawy.

\subsection{Przebieg postępowania habilitacyjnego w latach 2011-2018}

W myśl znowelizowanej ustawy z 2011 r. wszczęcie i przebieg postępowania habilitacyjnego poddano diametralnej zmianie. $W$ nowej sytuacji prawnej znalazły się trzy podmioty, bez których udziału przeprowadzenie postępowania nie byłoby możliwe: (1) kandydat do stopnia naukowego doktora habilitowanego, (2) właściwa rada jednostki organizacyjnej, (3) Centralna Komisja. I tej oceny w żadnym razie nie zmienia zachowanie w mocy niektórych z ustawowych rozwiązań dotyczących każdego z tych podmiotów. Wszczęcie postępowania w sprawie nadania stopnia naukowego doktora habilitowanego nadal wymagało wniosku kandydata; radzie wydziału i innych jednostek szkół wyższych oraz radzie naukowej PAN i instytutów badawczych służyło prawo podejmowania uchwał w sprawie nadawania stopnia naukowego doktora habilitowanego; Centralna Komisja zachowała gros swych ustawowych uprawnień. To, co było nowe, znacznie wykraczało jednak poza dotychczasowe ich uprawnienia. Zmieniło także przebieg postępowania habilitacyjnego. W myśl ustawy postępowania habilitacyjne miały przebiegać zgodnie z nowym scenariuszem, nieprzewidującym ani kolokwium habilitacyjnego, ani wykładu habilitacyjnego. O ile w rozwiązaniach dotyczących prawa nadawania stopni naukowych w latach minionych sporadycznie odstępowano od wygłoszenia wykładu habilitacyjnego, wyłączenie z przebiegu postępowania habilitacyjnego kolokwium habilitacyjnego było propozycją bezwzględnie nową - w istocie zmierzającą do obniżenia wagi postępowania habilitacyjnego, prowadzonego bez udziału habilitanta ( $\mathrm{z}$ jego udziałem tylko w sytuacjach 
ustawą przewidzianych), przez podejmowanie przez właściwą radę uchwały w sprawie nadania lub odmowy nadania stopnia doktora habilitowanego wyłącznie na podstawie wysłuchania przez członków danej rady na jej posiedzeniu opinii komisji habilitacyjnej.

Wbrew ogólnej ocenie szczegółowe rozwiązania były znacznie dalej odbiegające od rozwiązań przyjętych przed 2011 r., i to zarówno na etapie wszczęcia postępowania o nadanie stopnia naukowego doktora habilitowanego, jak i przebiegu tego postępowania. Nowy wymiar rozwiązań - będący swego rodzaju kompromisem między oczekiwaniem odstapienia od stopnia naukowego doktora habilitowanego a jego utrzymaniem - zgodnie z rządowym projektem ustawy (s. 6) - podporządkowano trzem podstawowym założeniom: (1) przyspieszeniu awansów naukowych przez skrócenie i uproszczenie postępowania habilitacyjnego jako rozwiązania modelowego, zastępującego wieloetapową oraz nadmiernie sformalizowaną ścieżkę kariery naukowej; w konsekwencji promującą (2) odmłodzenie kadry naukowej; przy jednoczesnym (3) podwyższeniu wymogów jakości osiągnięć naukowych będących podstawą promocji habilitacyjnych wychodzących poza ramy nauki wyłącznie krajowej (umiędzynarodowienie badań naukowych).

Osiągnięciu tych celów w postępowaniu habilitacyjnym służyć miały rozwiązania zakładające:

1. wszczęcie postępowania habilitacyjnego na wniosek osoby (od 2011 r. habilitanta ${ }^{90}$ ) ubiegającej się o nadanie stopnia naukowego doktora habilitowanego. Od 2011 r. odstąpiono od rozwiązań ustawy z 2003 r. przewidujących alternatywną drogę złożenia wniosku przez jednostkę organizacyjną za zgodą kandydata. W nowych uregulowaniach było to rozwiązanie zrozumiałe, słusznie podyktowane zapewnieniem osobie ubiegającej się o nadanie stopnia naukowego doktora habilitowanego wyboru jednostki organizacyjnej dla przeprowadzenia postępowania habilitacyjnego. Z reguły dotyczyło to wnioskujących osób zatrudnionych w jednostkach organizacyjnych nieposiadających takiego uprawnienia, ale także i tych (co gwarantowało elastyczność wyboru) zatrudnionych w jednostkach organizacyjnych w uprawnienie to wyposażonych. Wniosek mógł być złożony wyłącznie

${ }^{90}$ Zob. § 12 ust. 1 Rozporządzenia Ministra Nauki i Szkolnictwa Wyższego z dnia 22 IX 2011 r. w sprawie szczegółowego trybu i warunków przeprowadzania czynności w przewodach doktorskich, w postępowaniu habilitacyjnym oraz w postępowaniu o nadanie tytułu profesora. 
Centralnej Komisji ${ }^{11}$ (rozwiązanie nowe) wraz z autoreferatem (rozwiązanie nienowe), w języku polskim i angielskim (rozwiązanie nowe), $\mathrm{w}$ formie papierowej i elektronicznej, co Centralnej Komisji pozwalało ocenić wniosek również pod względem wymagań ustawowych. Od habilitanta wymagano poza posiadaniem stopnia doktora także osiągnięć naukowych lub artystycznych uzyskanych po otrzymaniu tego stopnia, stanowiących jego znaczny wkład w rozwój określonej dyscypliny naukowej (rozwiązanie nienowe) oraz wykazania się istotną aktywnością naukową lub artystyczną (rozwiązanie nowe). Na gruncie znowelizowanej w 2011 r. ustawy rozróżnienie obu sfer osiągnięć (aktywności) habilitanta mogło budzić wątpliwości, co nie jest bez znaczenia, zważywszy, że zgodnie z art. 16 ust. 2 w zw. z ust. 1 ustawy z 2011 r. oba komponenty oceny tworzyły równoprawną podstawę dla wszczęcia postępowania habilitacyjnego. Zgodnie z tym przepisem stanowiły je nadal: dzieło opublikowane w całości lub w zasadniczej części ${ }^{92}$ albo jednotematyczny cykl publikacji (od 2014 r. cykl publikacji powiązanych tematycznie ${ }^{93}$, co jest określeniem zdecydowanie precyzyjniejszym), zrealizowane oryginalne osiągnięcie projektowe, konstrukcyjne, technologiczne lub artystyczne bądź część pracy zbiorowej ( $\mathrm{z}$ dokładnym podaniem, $\mathrm{w}$ tym procentowo, indywidualnego wkładu habilitanta). Do wniosku przeciwnego prowadzą rozporządzenia ministra właściwego do spraw szkolnictwa wyższego. Pierwsze z nich, z dnia 1 września 2011 r. ${ }^{94}$, wyraźnie rozdziela kryteria oceny w zakresie osiągnięć naukowo-badawczych (w obszarach wiedzy) od kryteriów

${ }^{91}$ Dzień doręczenia Centralnej Komisji wniosku habilitanta wyznaczał jednocześnie datę wszczęcia postępowania habilitacyjnego (art. 18a ust. 2) w brzmieniu nadanym ustawą nowelizującą z 2011 r.).

${ }^{92} \mathrm{Z}$ tą jednak różnica, że zgodnie z zapowiedzią ujętą w uzasadnieniu rządowego projektu ustawy (s. 6) prawodawca, wymagając od habilitanta dzieła w jego dorobku naukowym, odstąpił (po raz pierwszy) od nadania temu dziełu dotychczasowej formy rozprawy habilitacyjnej „poza naukami humanistycznymi i społecznymi, gdzie dopuszczona jest możliwość składania rozprawy". Jakie ratio legis za sugestią (w prawie nieodzwierciedloną) pozostawienia prawa wyboru co do przygotowania rozprawy habilitacyjnej wyłącznie w obszarze tych dwóch dziedzin nauki przemawiało, trudno ustalić. Jeszcze trudniej, przy takim założeniu, znaleźć argumentację przemawiającą za uznaniem przez recenzentów rozprawy habilitacyjnej jako wiodącej w całokształcie dorobku naukowego habilitanta.

${ }^{93} \mathrm{~W}$ brzmieniu ustalonym art. 8 pkt 5 Ustawy z dnia 11 VII 2014 r. o zmianie ustawy - Prawo o szkolnictwie wyższym oraz niektórych innych ustaw (Dz.U. poz. 1198).

${ }^{94}$ Rozporządzenie Ministra Nauki i Szkolnictwa Wyższego z dnia 1 IX 2011 r. w sprawie kryteriów oceny osiągnięć osoby ubiegającej się o nadanie stopnia doktora habilitowanego (Dz.U. Nr 196, poz. 1165). 
oceny w zakresie dorobku dydaktycznego i popularyzatorskiego oraz współpracy międzynarodowej habilitanta. Podobne rozróżnienie przyjęto także rozporządzeniem drugim, z dnia 22 września 2011 r. ${ }^{95}$ Wyznaczone rozporządzeniem pierwszym kryteria oceny habilitanta w zakresie osiągnięć naukowo-badawczych ujęto osobno w sześciu punktach dla obszarów wiedzy ${ }^{96}$, luźno korespondujących z obszarami wiedzy przyjętymi rozporządzeniem z dnia 8 sierpnia 2011 r. (wymagających dla podkreślenia $w$ tej ocenie wagi m.in. publikacji osiągnięć naukowych habilitanta w czasopismach naukowych najwyżej w świecie punktowanych ${ }^{97}$ ) oraz kryteriami oceny wymagań wspólnych dla wszystkich obszarów wiedzy (wyznaczonych na nie mniej wysokim poziomie). Tej rewolucyjnej zmiany kryteriów oceny nie podzielało środowisko naukowe, niegotowe jeszcze do ich zrealizowania, mimo dwuletniego vacatio legis przewidującego możliwość wyboru złożenia wniosku o wszczęcie postępowania habilitacyjnego według nowych lub dotychczasowych przepisów prawnych. Dziwić więc nie mogło, że gros wnioskujących habilitantów (ale i rad właściwych jednostek organizacyjnych) optowało za przeprowadzeniem postępowania habilitacyjnego zgodnie z przepisami dotychczas obowiązującymi (przed 2011 r.).

Złożenie Centralnej Komisji przez habilitanta wniosku o wszczęcie postępowania habilitacyjnego wraz ze wskazaniem jednostki organizacyjnej posiadającej uprawnienie do nadawania stopnia naukowego doktora habilitowanego przez niego wybranej do przeprowadzenia postępowania habilitacyjnego od Komisji tej wymagało podjęcia

${ }^{95}$ Zob. $\$ 12$ ust. 1 i 2 Rozporządzenia Ministra Nauki i Szkolnictwa Wyższego z dnia 22 IX 2011 r. w sprawie szczegółowego trybu warunków przeprowadzania czynności w przewodach doktorskich, w postępowaniu habilitacyjnym oraz w postępowaniu o nadanie tytułu profesora (Dz.U. Nr 204, poz. 1200). Na jego podstawie można wywieść, że aktywność naukową miały ilustrować: osiągnięcia dydaktyczne habilitanta w przewodach doktorskich; współpraca z instytucjami, organizacjami i towarzystwami naukowymi albo działającymi w zakresie sztuki w kraju i za granica, a także działalność popularyzująca naukę.

${ }^{96}$ W obszarze nauk: humanistycznych; społecznych; ścisłych; technicznych; przyrodniczych, rolniczych, leśnych i weterynaryjnych oraz nauk medycznych, nauk o zdrowiu i nauk o kulturze fizycznej; w obszarze sztuki.

${ }^{97}$ Zgodnie z rozporządzeniem z dnia 1 IX 2011 r. każdy habilitant musiał w swoim wykazie dorobku naukowego m.in. przedstawić indeks Hirscha swoich publikacji opublikowanych według bazy Web of Science, sumaryczny impact factor własnych publikacji naukowych według listy JCR, ERIH (stosownie do obszaru wiedzy), kierowanie międzynarodowymi lub krajowymi projektami badawczymi lub udział w takich projektach ( $\$ 4$ rozporządzenia z dnia 1 IX 2011 r.). 
stosownych działań. Po pierwsze, to Centralnej Komisji ustawodawca powierzył ocenę formalną wniosku habilitanta i odpowiednio do niej podjęcie stosownych kroków - zarządzenie usunięcia uchybień formalnych $^{98}$; po drugie, Komisji tej pozostawiał rozstrzygnięcie problemu wynikłego z odmowy wyrażenia zgody przeprowadzenia postępowania habilitacyjnego przez wskazaną we wniosku habilitanta radę jednostki organizacyjnej uprawnionej do nadawania stopnia doktora habilitowanego. W sytuacji pierwszej - jedynie gdy wniosek nie uchybiał stawianym prawem wymaganiom, Centralna Komisja podejmowała dalsze czynności. W sytuacji drugiej z kolei ustawodawca legitymował Centralną Komisję do wyznaczenia jednostki organizacyjnej uprawnionej do nadawania stopnia doktora habilitowanego w terminie określonym dopiero od $2014 \mathrm{r} .{ }^{99}$ Alternatywnie tego wyboru nie pozostawiono więc wnioskodawcy, co może zastanawiać, zważywszy, że na każdym etapie wszczętego postępowania habilitacyjnego wnioskodawca mógł swój wniosek wycofać. Zapewne nie szło tu o możliwość odstąpienia od już rozpoczętego postępowania habilitacyjnego (wyznaczonego datą złożenia wniosku), skoro jednostka organizacyjna wyznaczona przez Centralną Komisję przeprowadzenia tego postępowania odmówić nie mogła.

Dopiero rozstrzygnięcie spełnienia wymagań stawianych wnioskodawcy oraz zgoda rady danej jednostki organizacyjnej uprawnionej do nadawania stopnia naukowego doktora habilitowanego do przeprowadzenia postępowania habilitacyjnego dawały podstawę do podjęcia dalszych etapów tego postępowania. Ich wypełnienie pozostawiono w gestii zarówno Centralnej Komisji, jak i właściwej rady jednostki organizacyjnej w zakresie:

2. przebiegu postępowania habilitacyjnego. Ustawodawca od Centralnej Komisji wymagał w terminie sześciu tygodni od dnia otrzymania wniosku habilitanta (bez uchybień formalnych bądź po

${ }^{98} \mathrm{~W}$ razie stwierdzenia niekompletności wniosku lub gdy ten nie odpowiadał ustawowym wymaganiom, Centralna Komisja wzywała w terminie 7 dni do jego uzupełnienia, zarazem wskazując zakres i termin uzupełnienia wniosku.

${ }^{99}$ Zob. $\$ 14$ ust. 2 rozporządzenia z 3 X 2014 r. - nim wyznaczono termin 14 dni od dnia otrzymania przez Centralną Komisję informacji o niewyrażeniu zgody na przeprowadzenie postępowania habilitacyjnego przez wybraną jednostkę organizacyjną $z$ uprawnieniem do nadawania stopnia doktora habilitowanego, oraz $\S 13$ ust. 2 rozporządzenia z dnia 30 X 2015 r., zgodnie z którym granice czasu wymagane dla podjęcia przez Centralną Komisję czynności w tym zakresie określono nową formułą - datą najbliższego posiedzenia statutowego organu Centralnej Komisji. 
ich uzupełnieniu) powołania siedmioosobowej komisji habilitacyjnej o uznanej renomie naukowej, w tym międzynarodowej, złożonej z przewodniczącego oraz sekretarza, członków i trzech recenzentów, Centralnej Komisji pozostawiając wybór przewodniczącego, członka oraz dwóch recenzentów spoza jednostki wybranej przez habilitanta lub jednostki przez Komisję tę wskazanej, natomiast radzie jednostki organizacyjnej wybór sekretarza i członka oraz jednego recenzenta (art. 18a ust. 5 ustawy z 2011 r.), nie zastrzegając tu wyboru przez radę recenzenta spoza jednostki organizacyjnej zatrudniającej habilitanta. W jakim trybie rada jednostki organizacyjnej miała przekazać Centralnej Komisji informację o wyborze osób uzupełniających skład komisji, ustawa milczała. Można było jedynie założyć, że kandydatów do komisji habilitacyjnej rada ta zgłaszała wraz z wyrażeniem zgody na przeprowadzenie postępowania $\mathrm{w}$ sprawie nadania stopnia doktora habilitowanego. I na etapie przekazania przez Centralną Komisję, z dniem powołania komisji habilitacyjnej, wniosku habilitanta wraz autoreferatem właściwej radzie jednostki organizacyjnej dalszy przebieg postępowania habilitacyjnego leżał już w gestii komisji habilitacyjnej i właściwej rady, przy założeniu przedłożenia przez recenzentów (w terminie sześciu tygodni od dnia powołania komisji) oceny, czy osiągnięcia naukowe wnioskodawcy (art. 18a ust. 7) spełniały kryteria ustawowo określone (w art. 16 ustawy). W razie wątpliwości komisji habilitacyjnej co do objętych dokumentacją osiągnięć naukowych wnioskodawcy komisja mogła przeprowadzić z nim rozmowę w zakresie jego osiągnięć naukowych i planów naukowych. W jaki sposób habilitant miał być powiadomiony o jego udziale w tej rozmowie i co miało być przedmiotem tej rozmowy, ustawa nie podała ${ }^{100}$. Nie podała także, kto mógłby być nadawcą takiego żądania i co miało wypełniać treść tej rozmowy. Można więc zakładać, że mogła być nią każda osoba wchodząca w skład komisji habilitacyjnej bez względu na powierzoną jej funkcję, byleby zdołała dowieść swoich

${ }^{100}$ Ustawowy obowiązek powiadomienia habilitanta przez komisję habilitacyjną o miejscu, terminie i przedmiocie planowanej rozmowy miały być rozstrzygnięte w drodze rozporządzenia ministra nauki i szkolnictwa wyższego. Tymczasem te ograniczyły się wyłącznie do wskazania terminu powiadomienia habilitanta. Pierwszym z nich wyznaczono termin co najmniej 14-dniowy przed wyznaczoną datą przeprowadzenia rozmowy z habilitantem ( $\$ 16$ ust. 1 rozporządzenia z dnia 22 IX 2011 r.), począwszy od 2015 r. - termin ten skrócono do co najmniej 7 dni przed rozmową ( $\$ 15$ ust. 1 rozporządzenia ministra nauki i szkolnictwa wyższego z dnia 30 X 2015 r.). I tego stanu prawnego nie zmieniono do czasu uchylenia rozporządzenia ministra nauki i szkolnictwa wyższego z dnia 19 I 2018 r. (§ 15 ust. 1). 
wątpliwości uzasadnionych szczególnym przypadkiem, pod warunkiem że komisja habilitacyjna je podzieli ${ }^{101}$. Po przedstawieniu recenzji i po zapoznaniu się $\mathrm{z}$ autoreferatem osoby tworzące komisję ${ }^{102} \mathrm{w}$ głosowaniu jawnym (tajnym na wniosek osoby ubiegającej się o nadanie stopnia naukowego doktora habilitowanego) podejmowały uchwałę ${ }^{103}$ zawierającą opinię w sprawie nadania lub odmowy nadania stopnia doktora habilitowanego. Sporządzenie tej opinii (w terminie $21 \mathrm{dni}$ od dnia otrzymania recenzji) wraz z uzasadnieniem i pełną dokumentacją, w tym recenzjami, prowadziło do etapu wieńczącego procedurę habilitacyjna, tj.

\section{3. podjęcia przez radę właściwej jednostki organizacyjnej stosow-} nej uchwały. Rada jednostki organizacyjnej mogła podjąć uchwałę o nadaniu stopnia naukowego doktora habilitowanego lub odmówić nadania tego stopnia naukowego ${ }^{104}$. W sytuacji pierwszej uchwała rady była prawomocna z chwilą jej podjęcia. W sytuacji drugiej natomiast

${ }^{101}$ Tu istotne znaczenie miał przepis wprowadzający zakaz powoływania w skład komisji habilitacyjnej osoby, w odniesieniu do której zachodzą uzasadnione wątpliwości co do jej bezstronności. W sposób niebudzący żadnej wątpliwości przesłankę tę określono, począwszy od 2015 r., Rozporządzeniem Ministra Nauki i Szkolnictwa Wyższego z dnia 30 X 2015 r. (§ 14 ust. 2) i zachowano kolejnymi rozporządzeniami Ministra Nauki i Szkolnictwa Wyższego z dnia 16 IX 2016 r. (§ 14 ust. 2) oraz z dnia 19 I 2018 r. (§ 14 ust. 2). Przepisy rozporządzeń Ministra Nauki i Szkolnictwa Wyższego z dnia 22 IX 2011 r. ( $\$ 15$ ust. 2) oraz z dnia 3 X 2014 r. (§ 15 ust. 1 w zw. z art. 6 ust. 2) wymogu bezstronności wymagały wprost od recenzentów i nakazywały odpowiednie stosowanie tego przepisu do członków komisji habilitacyjnej.

${ }^{102}$ W odróżnieniu od recenzji przepisy ustawy nowelizującej z 2011 r. ani wdrożone w kolejnych latach zmiany ustawy z 2003 r. oraz wydane na jej podstawie przepisy wykonawcze (również poddane zmianom po 2011 r.) nie tworzyły prawnego obowiązku sporządzania pisemnej opinii przez osoby powołane w skład komisji habilitacyjnej w charakterze członka. Nie znaczy to, że wyłączały jego prawo do wyrażenia swej opinii podczas posiedzenia komisji habilitacyjnej. Żądanie przez kierowników jednostek organizacyjnych przeprowadzających postępowanie habilitacyjne od członka komisji opinii pisemnej bez wątpienia nie znajdowało podstawy prawnej. Tym bardziej podstawy dla tego żądania stanowić nie mogły tzw. dobre praktyki. Nic więc dziwnego, że praktyka w tym zakresie nie była jednolita. Nieokreślenie roli członków w składzie komisji (w odróżnieniu od roli przewodniczącego, sekretarza i trzech recenzentów) nie bez powodu budziło także inną wątpliwość. Prowadziło do pytania o rzeczywisty cel włączenia członków w skład komisji habilitacyjnej z prawem głosu.

${ }^{103} \mathrm{~W}$ składzie nie mniejszym niż sześć osób, bezwzględnie w obecności przewodniczącego i sekretarza komisji habilitacyjnej.

${ }^{104}$ Rady (wydziału, naukowe) podejmowały uchwały w głosowaniu tajnym, bezwzględną większością głosów, przy obecności co najmniej połowy ogólnej liczby osób uprawnionych do głosowania. Tę grupę tworzyli: uprawnieni członkowie właściwej rady jednostki organizacyjnej posiadający tytuł profesora, stopień doktora habilitowanego, 
osobie ubiegającej się o nadanie stopnia doktora habilitowanego służyło odwołanie do Centralnej Komisji, za pośrednictwem rady właściwej jednostki organizacyjnej, w terminie miesiąca od dnia doręczenia jej uchwały wraz z uzasadnieniem. Centralna Komisja mogła albo utrzymać w mocy zaskarżoną uchwałę, albo - uchylając ją - przekazać sprawę do ponownego rozpatrzenia radzie tej samej lub innej jednostki organizacyjnej. Ale mogła też, w razie stwierdzenia rozbieżności między opiniami komisji habilitacyjnej a uchwałami rady jednostki organizacyjnej, po przeprowadzeniu postępowania wyjaśniającego, przeprowadzić okresową ocenę spełniania przez radę jednostki organizacyjnej warunków do nadawania stopnia naukowego doktora habilitowanego, a także zasadności podejmowanych przez nią w tym zakresie uchwał. W przypadku drugim - utrzymania w mocy uchwały - osobie ubiegającej się o nadanie stopnia doktora habilitowanego służyło prawo wystąpienia z ponownym wnioskiem o wszczęcie postępowania habilitacyjnego po upływie co najmniej 3 lat, z możliwością skrócenia tego okresu do 12 miesięcy w przypadku znacznego zwiększenia dorobku naukowego lub artystycznego (art. 21 ust. 3 ustawy z 2011 r.).

\section{Podsumowanie}

W okresie objętym analizą wymagania stawiane przed osobami ubiegającymi się o nadanie stopnia naukowego doktora habilitowanego podlegały zmianom. Zmieniały się także warunki prowadzenia przewodów (od 2011 r. postępowań) habilitacyjnych. Kierunki proponowanych reformami zmian $\mathrm{z}$ reguły zmierzały do stopniowego zaostrzenia wymagań stawianych zarówno przed osobami kandydującymi do stopnia naukowego doktora habilitowanego, jak i przed radami jednostek organizacyjnych aspirujaccych do otrzymania uprawnienia do nadawania tego stopnia naukowego. Jedynie początkowe lata dziewięćdziesiąte ubiegłego stulecia temu założeniu przeczyły. Począwszy od 1990 roku, rozwiązania dotyczące postępowań habilitacyjnych i wymagań stawianych przed kandydatami do stopnia doktora habilitowanego określono na poziomie niższym i na warunkach ogólniej określonych aniżeli w rozwiązaniach przyjętych pod rządami ustawy z 1965 r., szczególnie w brzmieniu nadanym jej w roku 1985. Wprawdzie kolejna ustawa

a także osoby, które nabyły uprawnienia równoważne z uprawnieniami doktora habilitowanego na podstawie art. 21a. 
z 2003 r. zachowała trzon rozwiązań przyjętych ustawą z 1990 r., znacznie szerzej i precyzyjniej formułowała jednak warunki stawiane przed osobami wnioskującymi o nadanie stopnia naukowego doktora habilitowanego, ale i przed jednostkami organizacyjnymi wnioskującymi o otrzymanie uprawnienia do jego nadawania. Mimo pewnych słabości, które można zarzucić tym rozwiązaniom, ich niepodważalną wartością, bez wątpienia, było zagwarantowanie wolności nauki, w tym prowadzonych badań naukowych.

Rozwiązania przyjęte w 2011 r. zdecydowanie odstąpiły od większości rozwiązań wcześniej przyjętych. W sposób rewolucyjny zmieniły warunki wszczęcia i przeprowadzania postępowań habilitacyjnych. Wprowadziły nowe kryteria oceny habilitanta. W postępowaniach habilitacyjnych odstąpiono od kolokwium habilitacyjnego i wygłoszenia przez habilitanta wykładu habilitacyjnego. Już nie rada właściwej jednostki organizacyjnej, lecz Centralna Komisja była organem uprawnionym do wszczęcia postępowania habilitacyjnego. Jej też pozostawiono, przy zawężonym współdziałaniu z radą jednostki organizacyjnej uprawnionej do nadawania stopnia doktora habilitowanego, wyłonienie komisji (i jej składu) uprawnionej do przeprowadzenia postępowania habilitacyjnego. Dla rad właściwych jednostek organizacyjnych nadal zachowano prawo do podjęcia na swym posiedzeniu uchwały o nadaniu lub o odmowie nadania stopnia doktora habilitowanego. Jedynie jej rozstrzygnięcie pozytywne czyniło uchwałę danej rady (wydziału, naukowej) prawomocną z chwilą jej podjęcia.

\section{HABILITACJA AS A CONDITION OF SCIENTIFIC ADVANCEMENT IN POLAND IN THE YEARS 1990-2018}

\section{Su m m a ry}

The right to conduct habilitacja ("habilitation") proceedings under Polish law is not a new solution. These proceedings were conducted both in the interwar period, in the first years of the People' s Poland, and during the Polish People's Republic. The solutions adopted in those periods differed. Until the end of People's Poland, the proceedings ended with the right to lecture (veniam legendi) but with no possibility of obtaining a scientific degree, in the years 1951-1958, following the example of Soviet solutions, the proceedings allowed to obtain a scientific degree of doctor of sciences, from 1958 to obtain a degree of a docent (assistant professor), and from 1968 - the degree of doktor habilitowany. The differences in legal solutions adopted at that time were also clearly visible in the conditions which higher 
education institutions had to meet in order to obtain the right to conduct the proceedings and confer titles, and candidates to be promoted to a higher degree of doktor habilitowany.

Although the possibility of acquiring the degree of doktor habilitowany was retained from 1990 onwards, the legal conditions for the conduct of habilitacja proceedings did not resemble the solutions of previous years. And so, as in the Act of 1965, as well as after 1990 the conferral of academic degrees was excluded from the law on higher education, but this law itself was subject to much more modest regulation. It was not until the Act of 2003 that solutions were introduced to gradually tighten the conditions imposed on organisational units applying for the right to confer the academic degree of doktor habilitowany and on persons applying for the initiation of habilitacja proceedings, as well as on the course of such proceedings.

The year 2011 brought revolutionary changes in this respect. The amending law introduced a new order in the process leading to the conferral of the academic degree of doktor habilitowany. It covered not only the requirements which organisational units applying for the right to 'habilitate' in the fields of science and scientific disciplines had to satisfy, but also a re-definition of these conditions. The course of the 'habilitation' proceedings and the participation in it of the Central Commission and the board of the relevant organisational unit, as well as the person applying for the degree of doktor habilitowany were significantly changed.

Keywords: the right to confer the academic degree of doktor habilitowany in the years 1990-2018 - the right to conduct 'habilitation' proceedings - the conditions for instituting and conducting 'habilitation' proceedings - resolutions on the conferral or refusal to confer the academic degree of doktor habilitowany 